\title{
Is Cost Recovery a Feasible Objective for Water and Electricity? \\ The Latin American Experience
}

\author{
Vivien Foster and Tito Yepes \\ The World Bank
}

\begin{abstract}
One of the most commonly cited obstacles to cost recovery tariffs is the problem of affordability of basic utility services by residential households, and low income families in particular. However, a careful analysis of income distribution in the region suggests that only about $20 \%$ of Latin American households would have to pay more than 5\% of their income for water or electricity services if tariffs were set at cost recovery levels. However, in the region's lower income countries (Bolivia, Honduras, Nicaragua, Paraguay), reaching cost recovery tariffs would represent a significant affordability problem for around half of the population. Even in cases where tariffs might have to double to reach cost recovery levels, the overall impact on poverty levels in Latin America would be negligible. These results can be compared to those for India and Africa where around $70 \%$ of households could be expected to face difficulties in paying full cost recovery tariffs. In these regions, tariffs would likely have to increase by a factor of ten to reach cost recovery levels, and this could be expected to have a significant

impact on poverty.
\end{abstract}

JEL Classification: I3, N7, H54, L95, Q25, Q4

Keywords: Latin America, water, electricity, affordability, basic needs

\section{World Bank Policy Research Working Paper 3943, June 2006}

The Policy Research Working Paper Series disseminates the findings of work in progress to encourage the exchange of ideas about development issues. An objective of the series is to get the findings out quickly, even if the presentations are less than fully polished. The papers carry the names of the authors and should be cited accordingly. The findings, interpretations, and conclusions expressed in this paper are entirely those of the authors. They do not necessarily represent the view of the World Bank, its Executive Directors, or the countries they represent. Policy Research Working Papers are available online at http://econ.worldbank.org.

We are grateful to Marianne Fay, Antonio Estache and Jonathan Halpern for their suggestions and advice. We are particularly indebted to ADERASA and OLADE for sharing their tariff data. 


\section{Introduction}

There are only two possible ways of paying for infrastructure services: through fiscal transfers financed by tax payers, or through user charges financed by consumers.

Moreover, the participation of the private sector does not materially alter this underlying reality, since finance raised in private capital markets must ultimately be remunerated either through fiscal transfers or user charges.

This paper focuses on user charges as a mechanism for infrastructure financing. For some components of infrastructure with strong public good characteristics - for example rural roads - user charges are not a feasible option. For other components of infrastructure -notably telecommunications - full cost recovery through user charges is not only feasible but has widely become the norm in Latin America and hence does not warrant any major comment. This chapter focuses on two major areas of infrastructure-water and electricity_where cost recovery is technically feasible and economically attractive but may be politically difficult to achieve.

During the 1990s, the majority of countries in Latin America passed sector reform legislation espousing principles of cost recovery for water and electricity services. Cost recovery was a key prerequisite for reducing the fiscal burden associated with these sectors, and opening the doors to private sector participation. However, ten years later, it is apparent that the transition to cost recovery pricing has been much more challenging than originally supposed.

Despite substantial efforts to raise tariffs in nominal local currency terms, a large part of these gains have been wiped out by price inflation and currency devaluation. Nevertheless, Latin American utility tariffs are currently the highest of any developing region and above the average for upper middle income countries. Analysis of household income distribution shows that, except in a handful of the poorest countries, only a small segment of the population in Latin America (around 20\%) faces genuine affordability problems in paying cost recovery tariffs, far fewer than in other developing regions. As a result, there is considerable potential for targeted subsidies to reconcile cost recovery and social protection objectives. Nevertheless, the increasing block tariff structures, which are the region's most prevalent form of social policy, tend to be poorly designed failing to make a significant contribution in this direction.

This paper begins by evaluating to what extent Latin American water and electricity utilities have advanced towards the cost recovery goal during the last decade, comparing them where possible to their peers in other regions of the world. It goes on to consider why cost recovery has proved to be such an elusive goal, focusing on the problem of affordability among low income households. Finally, it considers to what extent Latin American countries have succeeded in establishing effective safety nets for water and electricity services that might allow some reconciliation between the goals of cost recovery and social protection. 


\section{The Goal of Cost Recovery}

The discussion begins by evaluating to what extent Latin American electricity and water utilities succeeded in advancing towards the cost recovery goal enshrined in the new regulatory frameworks of the 1990s. In order to put the achievements in perspective, benchmark comparisons against other regions will be performed wherever data permits.

The ideal methodology for measuring cost recovery would be to take the average tariff for each utility and compare it against the full average cost of production for that particular utility. Unfortunately, there is very little public information available about the full average cost of service provision, making this approach almost impossible to apply on a regional scale. Instead a simpler approach is taken, establishing indicative ranges within which tariffs would need to fall in order to have a high probability of recovering either operation and maintenance costs or full capital costs. These ranges are based on expert estimates.

It is important to acknowledge that this methodology does not enable us to say with precision when a particular utility is achieving full cost recovery. However, it does enable us to identify utilities that are not achieving full cost recovery. Moreover, it allows us to classify utilities into three broad groups. In the first group are utilities whose tariffs are so low that they are extremely unlikely to be meeting even operation and maintenance costs. In the second group are utilities whose tariffs are at a level that is likely to be commensurate with operation and maintenance costs, but is extremely unlikely to leave over any significant contribution towards capital costs. In the third group are utilities whose tariffs are high enough to be making a significant contribution towards capital costs. Exact details of how this approach is applied to the water and electricity sectors are given below.

\section{Water}

The water sector in Latin America has become highly decentralized during the last two decades and information on tariffs in smaller cities is very limited. The analysis is therefore based on tariff data from around 15 utilities serving the region's larger cities for the period 1997 to 2003 (ADERASA, forthcoming). The group also includes one or two national level utilities serving smaller countries, such as Costa Rica and Uruguay. Given that tariff levels in larger cities tend to be higher than those in smaller cities, the true status of cost recovery is likely to be significantly worse than what can be portrayed through this analysis.

Local currency tariff trends provide a good indication of the degree of 'effort' that different utilities made to raise their tariffs towards cost recovery levels. The results show that 13 Latin American water utilities raised their residential tariffs in nominal terms at an average annual rate of $8 \%$ over the period 1997/03 (Figure 1). Nevertheless, these gains were largely wiped out by inflation, with real residential tariffs rising by less than $1 \%$ per year on average over the same period. In the case of industrial customers, water tariffs rose in nominal terms at an average annual rate of $4 \%$ over the period 1997/03. However, 
in real terms, this translated into an average annual decline of $3 \%$ over the same period. The lower growth rates observed for industrial tariffs relative to residential tariffs reflect a tendency to try and reduce the large divergence between tariffs paid by these two customer groups, given that industrial tariffs in Latin America tend to be two or three times as high as residential tariffs. Details of the Colombian experience with raising water tariffs are documented in Box 1.

Figure 1: Average annual change in water tariffs 1997/03

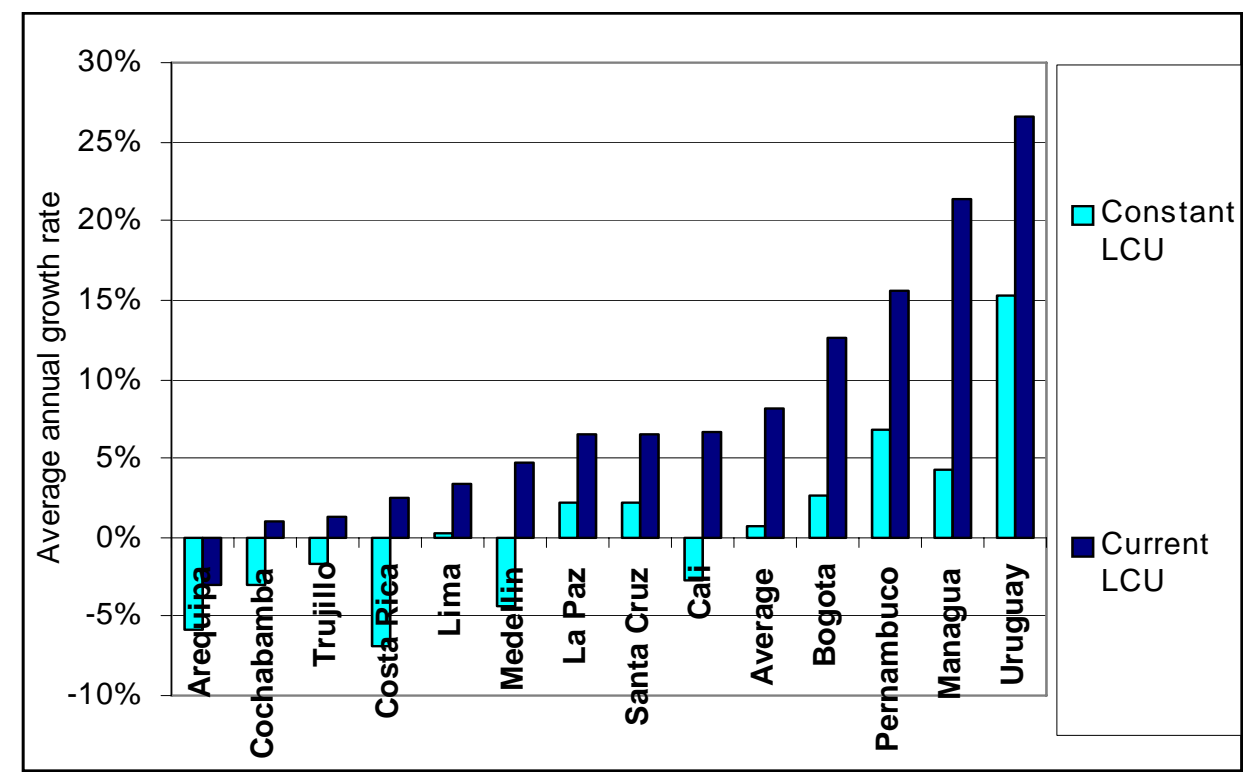

Source: Adapted from ADERASA, forthcoming 


\section{Box 1: Colombian experience with raising residential water tariffs}

In 1994, Colombia passed the Public Services Law requiring reference utility tariffs to rise to full cost recovery levels. The law also limited the extent of cross-subsidies between customers, so that poor households should always pay at least $50 \%$ of the full cost of the service, while better off households should pay no more than $20 \%$ over and above the full cost of service in order to finance cross-subsidies to poor households. A two year deadline was established for the completion of this tariff rebalancing.

However, the magnitude of the tariff increases required to meet these legal goals was extremely large, and moreover regressively distributed. An increase of $50 \%$ was required to bring the reference tariff in line with full cost recovery. Furthermore, due to the fact that cross-subsidies were historically much larger than those prescribed by law, the tariffs of the poorest households would have had to rise by $400 \%$ in real terms. Given the social and political difficulties entailed, the legal deadline was twice extended, first by five years (from 1996 to 2001 by Law 286/96) and then by a further four years (from 2001 to 2005 by Law 632/01). In the meantime, the requirement for poor households to pay at least $50 \%$ of the full cost of service provision was reduced to $30 \%$ of full cost. Ten years after the reform law, reference tariffs have now reached cost recovery levels. However, higher income consumers continue to pay surcharges of $30-60 \%$ on their bills in order to compensate for the large subsidies still applied to lower income groups.

Owing to the broad definition of low income groups used in the Colombian tariff system, about $80 \%$ of residential customers qualify as eligible to benefit from cross-subsidies. Thus, notwithstanding the progress made towards the tariff objectives established in the 1994 Public Services Law, the water sector continues to make substantial fiscal demands. The Colombian government transferred an average of US\$240 million per year to municipally operated water utilities over the period 1998/01, which accounted for $80 \%$ of the resources available for investment in the sector.

Source: Adapted from Colombia Recent Economic Developments in Infrastructure, World Bank 2004

Given these tendencies, to what extent do current water tariffs succeed in covering the full costs of service provision? The direct evidence is limited. A recent survey of water tariffs conducted by regulatory agencies in Latin America concluded that residential tariffs in 10 large cities on average fall short of full cost recovery by around $30 \%$, while industrial tariffs may exceed cost recovery levels by around 20\% (ADERASA, forthcoming). In the case of Asia, a recent review of water tariffs in 18 large cities reports that only half of them are high enough to cover full operating and maintenance costs (ADB, 2004).

Thus, in order to provide a broader evaluation of cost recovery, the analysis will refer to indicative ranges within which tariffs would need to fall in order to have a high probability of recovering either operation and maintenance costs or full capital costs. The ranges are taken from GWI 2004 and summarized in Table 1 below. They are broadly consistent with estimates of a global reference price for water made by Kingdom, Van Ginneken and Brocklehurst (forthcoming). These authors set a reference value of US $\$ 0.30$ per cubic meter for operation and maintenance costs, and a reference value of US\$0.90 per cubic meter for full capital costs (including operation and maintenance costs). 
Table 1: Thresholds used for evaluating cost recovery of water tariffs

\begin{tabular}{|c|c|c|}
\hline & Developing countries & Industrialized countries \\
\hline$<\mathrm{US} \$ 0.20 / \mathrm{m}^{3}$ & $\begin{array}{l}\text { Tariff insufficient to cover basic operating } \\
\text { and maintenance costs }\end{array}$ & $\begin{array}{l}\text { Tariff insufficient to cover basic } \\
\text { operating and maintenance costs. }\end{array}$ \\
\hline US $\$ 0.20-0.40 / \mathrm{m}^{3}$ & $\begin{array}{l}\text { Tariff sufficient to cover operating and } \\
\text { some maintenance costs }\end{array}$ & $\begin{array}{l}\text { Tariff insufficient to cover basic } \\
\text { operating and maintenance costs. }\end{array}$ \\
\hline US $\$ 0.40-1.00 / \mathrm{m}^{3}$ & $\begin{array}{l}\text { Tariff sufficient to cover operating, } \\
\text { maintenance and most investment needs }\end{array}$ & $\begin{array}{l}\text { Tariff sufficient to cover operating and } \\
\text { maintenance costs }\end{array}$ \\
\hline$>\mathrm{US} \$ 1.00 / \mathrm{m}^{3}$ & $\begin{array}{l}\text { Tariff sufficient to cover operating, } \\
\text { maintenance and most investment needs } \\
\text { in the face of extreme supply shortages }\end{array}$ & $\begin{array}{l}\text { Tariff sufficient to cover full cost of } \\
\text { modern water systems in most high- } \\
\text { income cities }\end{array}$ \\
\hline
\end{tabular}

Source: GWI, 2004

Based on this framework, it is possible to assess the progress actually made towards cost recovery over this period by expressing tariffs in US dollar terms and comparing them against these benchmarks (Table 2) ${ }^{1}$. The average real residential water tariff in the 13 Latin American cities considered rose from US\$0.47 to US\$0.51 per cubic meter. However, this result is driven by some particularly large tariff increases in Colombia (recall Box 1), so that the median tariff actually fell from US\$0.51 to US\$0.38 per cubic meter. As a result, the percentage of utilities within the indicative range for some degree of capital cost recovery fell from $62 \%$ to $46 \%$. However, the number of utilities whose tariffs do not even cover operation and maintenance expenditures fell from $8 \%$ of the sample to $0 \%$. The average real industrial tariff fell substantially from US\$1.91 to US\$1.11 over the period 1997/03. Nevertheless, industrial tariffs in 1997 were so far above cost recovery levels that even a decline of this magnitude did not bring them below the threshold for full capital cost recovery in any of the utilities considered.

\footnotetext{
${ }^{1}$ The real tariff trends reported in LCU in Figure 1 do not necessarily coincide with the real tariff trends reported in US\$ terms in Table 2. The differences are due to the fact that some countries experienced a depreciation of the real exchange rate against the US\$, while others experienced an appreciation of the real exchange rate against the US\$ over the same period. A more extensive explanation of this issue is provided in Appendix 1.
} 
Table 2: Real water tariff trends in 13 Latin American cities

\begin{tabular}{|l|l|l|l|l|}
\hline & \multicolumn{3}{l}{ Residential } & \multicolumn{3}{l|}{ Industrial } \\
\hline Average tariffs (US\$/m3) & 1997 & 2003 & 1997 & 2003 \\
Arequipa & 0.38 & 0.22 & 1.29 & 0.69 \\
Bogota & 0.63 & 1.16 & 1.76 & 1.58 \\
Cali & 0.58 & 0.76 & 1.99 & 1.47 \\
Cochabamba & 0.43 & 0.32 & 1.29 & 0.83 \\
Costa Rica & 0.54 & 0.34 & 4.54 & 1.80 \\
La Paz & 0.24 & 0.22 & 1.52 & 1.19 \\
Lima & 0.38 & 0.32 & 1.29 & 0.93 \\
Managua & 0.21 & 0.31 & 1.37 & 0.57 \\
Medellin & 0.65 & 0.78 & 1.84 & 1.22 \\
Pernambuco & 0.67 & 0.51 & 3.89 & 1.35 \\
Santa Cruz & 0.65 & 0.59 & 0.94 & 0.74 \\
Trujillo & 0.51 & 0.38 & 1.21 & 1.02 \\
Uruguay & 0.19 & 0.72 & 1.24 & 1.11 \\
& & & & \\
Average & 0.47 & 0.51 & 1.91 & 1.11 \\
Median & 0.51 & 0.38 & 1.44 & 1.11 \\
Minimum & 0.19 & 0.22 & 0.94 & 0.57 \\
Maximum & 0.67 & 1.16 & 4.54 & 1.80 \\
& & & & \\
\hline Cost recovery (\% cases) & & & & \\
Partial capital costs & 62 & 46 & 100 & 100 \\
Partial O\&M costs & 31 & 54 & 0 & 0 \\
Nil & 8 & 0 & 0 & 0 \\
\hline
\end{tabular}

Source: Adapted from ADERASA, forthcoming and GWI 2004

It is interesting to see how water tariffs in Latin America currently compare with those in other regions (Table 3). The comparisons are based on a sample of 132 water utilities serving major cities worldwide.

Average residential water tariffs in OECD countries currently stand at US $\$ 1.04$ per cubic meter. However, even in OECD countries, only around half of water utilities have tariffs high enough to make a substantial contribution to capital costs. Among developing regions of the world, Latin America has the strongest record on cost recovery. The results show that water tariffs in Latin America are on average about $40 \%$ of those observed in OECD countries, although given higher costs of service provision in OECD countries the percentage of utilities whose tariffs make some contribution to capital costs is quite similar to that in Latin America. Latin America has the highest prices of any developing region of the world, with median water tariffs twice as high as those observed in East Asia, Eastern Europe, and the Middle East, and more than six times as high as those observed in South Asia ${ }^{2}$.

\footnotetext{
${ }^{2}$ The average tariffs reported for Latin America in Tables 2 and 3 differ somewhat owing to the use of a different sample. The data in Table 2 are based on a sample of 13 water utilities for which tariff trends over time are available. The data in Table 3 are based on a sample of 23 water utilities for which only the most recent tariff is available.
} 
In general, there is a strong relationship between cost recovery and the income level of the country. Overall, the correlation coefficient between water tariffs and per capita GDP stands at 0.39 . Average tariffs rise from around US\$0.10 per cubic meter in low-income countries, to US $\$ 0.30$ per cubic meter in middle-income countries and US\$1.00 per cubic meter in high-income countries. The percentage of utilities whose tariffs make some significant contribution to covering capital costs rises correspondingly from less than 5\% in low-income countries to around $30 \%$ in middle-income countries, and $50 \%$ in highincome countries. In this context, it is striking that the performance of Latin America is substantially better than that of the group of upper-middle-income countries as a whole.

Table 3: Overview of average residential water tariffs

\begin{tabular}{|c|c|c|c|c|c|c|c|c|c|c|}
\hline & $\begin{array}{l}\text { Mean } \\
\left(\mathrm{US} \$ / \mathrm{m}^{3}\right)\end{array}$ & $\begin{array}{l}\text { Median } \\
\left(\mathrm{US} \$ / \mathrm{m}^{3}\right)\end{array}$ & $\begin{array}{l}\text { Standard } \\
\text { deviation } \\
\left(\mathrm{US} \$ / \mathrm{m}^{3}\right)\end{array}$ & $\begin{array}{l}\text { Rans } \\
\text { (US } \\
\text { Min }\end{array}$ & $\begin{array}{l}\left.\mathrm{n}^{3}\right) \\
\operatorname{Max}\end{array}$ & $\begin{array}{l}\text { Inter } \\
\text { rang } \\
\text { (US } \\
\text { Min }\end{array}$ & $\begin{array}{l}\text { uartile } \\
\left.\mathrm{n}^{3}\right) \\
\text { Max }\end{array}$ & $\begin{array}{l}\text { Deg } \\
\text { cost } \\
(\%) \\
\text { Nil }\end{array}$ & $\begin{array}{l}\text { of } \\
\text { covery } \\
\text { Partial } \\
\text { O\&M }\end{array}$ & $\begin{array}{l}\text { Partial } \\
\text { capital }\end{array}$ \\
\hline Global & 0.53 & 0.35 & 0.50 & 0.00 & 1.97 & 0.13 & 0.85 & 39 & 30 & 30 \\
\hline $\begin{array}{l}\text { By income } \\
\text { HIC } \\
\text { UMIC } \\
\text { LMIC } \\
\text { LIC }\end{array}$ & $\begin{array}{l}1.00 \\
0.34 \\
0.31 \\
0.11\end{array}$ & $\begin{array}{l}0.96 \\
0.35 \\
0.22 \\
0.09\end{array}$ & $\begin{array}{l}0.45 \\
0.24 \\
0.19 \\
0.09\end{array}$ & $\begin{array}{l}0.00 \\
0.03 \\
0.04 \\
0.01\end{array}$ & $\begin{array}{l}1.97 \\
0.81 \\
0.85 \\
0.45\end{array}$ & $\begin{array}{l}0.60 \\
0.15 \\
0.19 \\
0.05\end{array}$ & $\begin{array}{l}1.37 \\
0.57 \\
0.39 \\
0.16\end{array}$ & $\begin{array}{l}8 \\
39 \\
37 \\
89\end{array}$ & $\begin{array}{l}42 \\
22 \\
41 \\
9\end{array}$ & $\begin{array}{l}50 \\
39 \\
22 \\
3\end{array}$ \\
\hline $\begin{array}{l}\text { By region } \\
\text { OECD } \\
\text { LAC } \\
\text { MENA } \\
\text { EAP } \\
\text { ECA } \\
\text { SAS }\end{array}$ & $\begin{array}{l}1.04 \\
0.41 \\
0.37 \\
0.25 \\
0.13 \\
0.09\end{array}$ & $\begin{array}{l}1.00 \\
0.39 \\
0.15 \\
0.20 \\
0.16 \\
0.06\end{array}$ & $\begin{array}{l}0.45 \\
0.19 \\
0.39 \\
0.13 \\
0.07 \\
0.05\end{array}$ & $\begin{array}{l}0.00 \\
0.12 \\
0.03 \\
0.04 \\
0.01 \\
0.02\end{array}$ & $\begin{array}{l}1.97 \\
0.81 \\
1.17 \\
0.53 \\
0.20 \\
0.22\end{array}$ & $\begin{array}{l}0.70 \\
0.22 \\
0.03 \\
0.18 \\
0.08 \\
0.05\end{array}$ & $\begin{array}{l}1.37 \\
0.54 \\
0.60 \\
0.30 \\
0.17 \\
0.12\end{array}$ & $\begin{array}{l}6 \\
13 \\
58 \\
53 \\
100 \\
100\end{array}$ & $\begin{array}{l}43 \\
39 \\
25 \\
32 \\
0 \\
0\end{array}$ & $\begin{array}{l}51 \\
48 \\
17 \\
16 \\
0 \\
0\end{array}$ \\
\hline
\end{tabular}

Sources: ADB, 2001; ADERASA, 2003; GWI, 2004; NIUA, 1999

Notes: Average tariffs are based on residential consumption of 15 cubic meters

Data drawn from utilities serving 132 major cities worldwide, broken down as follows:

OECD (47), SAS (24), LAC (23), EAP (19), MENA(12), ECA(6).

In summary, water tariffs in Latin America's larger water utilities have not risen substantially on average over the period 1997/03, although some individual operators have made substantial efforts to increase prices towards cost recovery levels. As a result, the percentage of water utilities whose tariffs make a significant contribution to capital costs has declined slightly. However, at the other end of the spectrum, all of the utilities considered had managed to reach tariff levels commensurate with the recovery of operation and maintenance expenditures. As things currently stand, Latin America has the highest water tariffs of any developing region. At US\$0.41 per cubic meter they are still only $40 \%$ of those applied in OECD countries; however given the higher cost levels faced by industrialized countries the percentage of utilities whose tariffs make a substantial contribution to capital costs is not so dissimilar. Finally, it is important to recall that the results presented here over-state the true extent of cost recovery to the extent that they are based on data from utilities serving major cities that tend to also be the ones charging the highest prices. 


\section{Electricity}

The information base on electricity tariffs is much more extensive than that available for the case of water. The analysis draws on the regional database developed by OLADE (2004) that provides average tariffs at the country level for different customer classes. As a result, it is possible to draw a more comprehensive picture as to the current extent of cost recovery for electricity.

The results show that 13 Latin American electric utilities made substantial efforts to raise their residential tariffs in nominal terms at an average annual rate of $22 \%$ over the period 1990/02 (Figure 2). Nevertheless, these gains were largely wiped out by inflation, with real residential tariffs rising by no more than $2 \%$ per year on average over the same period. In the case of industrial customers, electricity tariffs rose in nominal terms at an average annual rate of $18 \%$ over the period 1997/03. However, in real terms, this translated into an average annual decline of $1 \%$ over the same period. In contrast to the water sector, industrial electricity tariffs tend to be lower than residential tariffs.

It is interesting to compare tariff trends in Latin America with those observed in other regions of the world (Figure 3). Looking at the period 1995/00, for which comparable data is available, South Asia, Eurasia and East Asia sustained much larger real tariff increases than Latin America of between 4-9\% per year in local currency terms. However, real residential electricity tariffs in OECD countries declined in real terms over the same period. Notwithstanding these differences in trend, residential electricity tariffs in Latin America remain the highest of any developing region in absolute terms, although they still fall substantially short of those in OECD countries (Figure 4). 
Figure 2: Average annual change in residential electricity tariffs in Latin America 1990/02

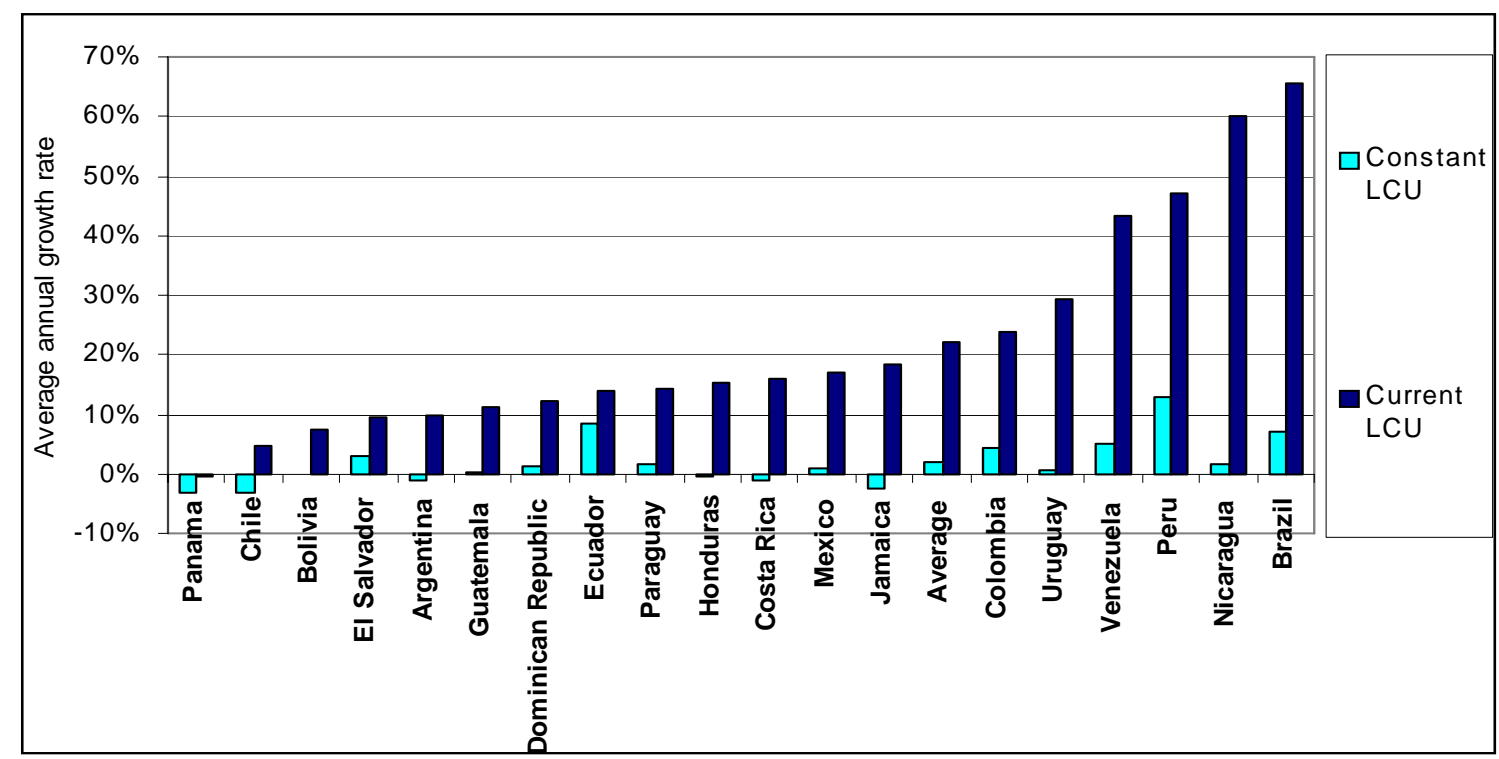

Source: OLADE, 2004

Figure 3: Real average annual increase in local currency residential electricity tariffs by region 1995/00

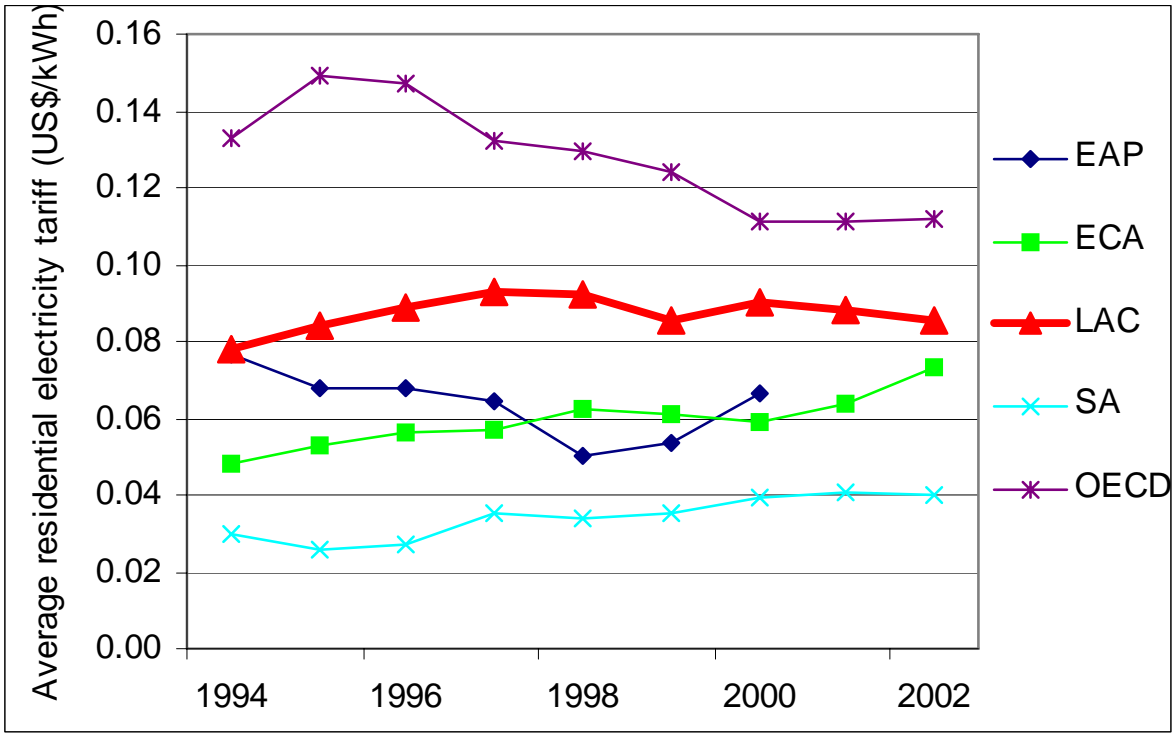

Sources: OECD 2004, ERRA 2004, EIA 2004, OLADE 2004, UN-ESCAP 2004.

Notes: Data drawn from 84 countries worldwide, broken down as follows OECD (23), LAC (19), ECA(18), EAP (8), SAS (3) 
Figure 4: Comparative regional trends in residential electricity tariffs 1994/02

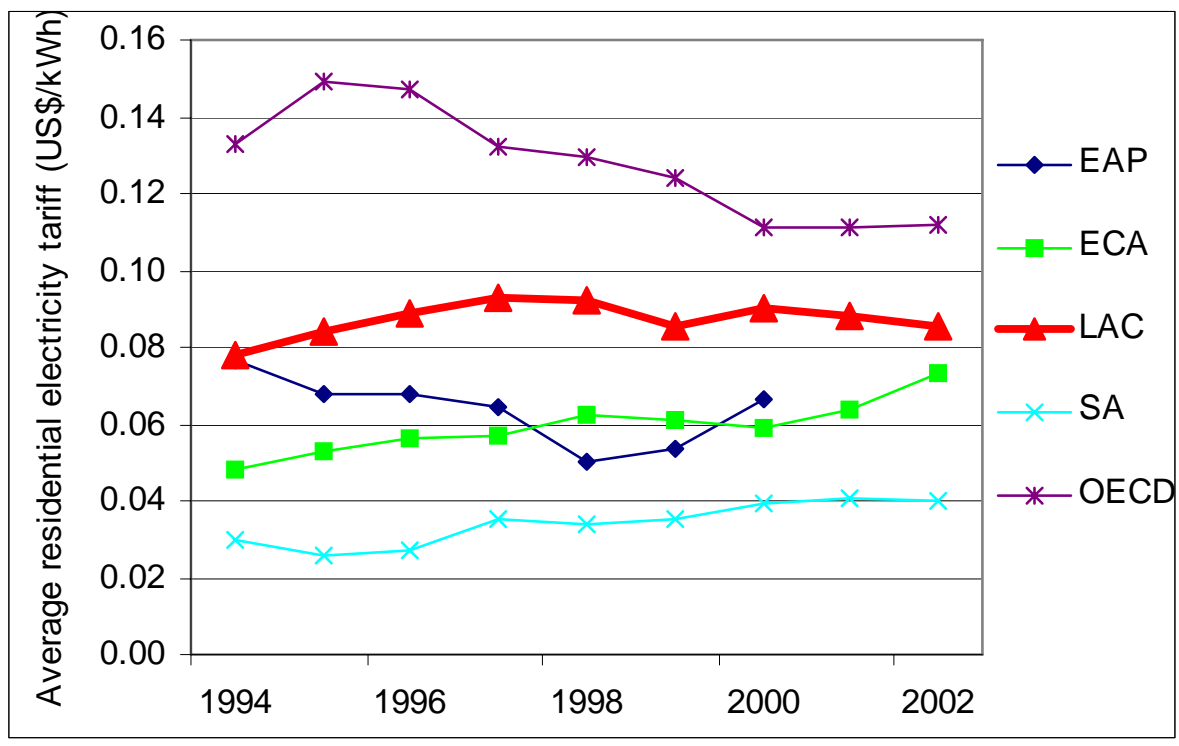

Sources: OECD 2004, ERRA 2004, EIA 2004, OLADE 2004, UN-ESCAP 2004.

Notes: Data drawn from 84 countries worldwide, broken down as follows OECD (23), LAC (19), ECA(18), EAP (8), SAS (3)

In order to provide a broader evaluation of cost recovery, the analysis will refer to a number of indicative ranges within which tariffs would need to fall in order to have a high probability of recovering either operation and maintenance costs or full capital costs. These ranges are based on discussion with international experts on electricity tariffs summarized in Table 4 below. Different thresholds are provided for residential and industrial customers to reflect the lower cost of service provision to the latter group.

Table 4: Thresholds used for evaluating cost recovery of electricity tariffs

\begin{tabular}{|l|l|l|}
\hline & Residential customers & Industrial customers \\
\hline$<$ US\$0.04/kWh & $\begin{array}{l}\text { Tariff insufficient to cover basic } \\
\text { operating and maintenance costs }\end{array}$ & $\begin{array}{l}\text { Tariff insufficient to cover basic } \\
\text { operating and maintenance costs. }\end{array}$ \\
\hline$>$ US $\$ 0.05 / \mathrm{kWh}$ & $\begin{array}{l}\text { Tariffs likely to be making a significant } \\
\text { contribution towards capital costs, in } \\
\text { most types of systems. }\end{array}$ \\
\hline$>\mathrm{US} \$ 0.08 / \mathrm{kWh}$ & $\begin{array}{l}\text { Tariffs likely to be making a significant } \\
\text { contribution towards capital costs, in } \\
\text { most types of systems. }\end{array}$ & \\
\hline
\end{tabular}

Source: Own elaboration

Based on this framework, it is possible to assess the evolution in the absolute value of the average residential electricity tariff expressed in dollar terms. The average residential electricity tariff in the 19 Latin American countries considered rose from US\$0.07 to US $\$ 0.10$ per kilowatt-hour between 1990/96, falling back down to US $\$ 0.09$ per kilowatthour by 2002. Correspondingly, the percentage of countries recovering some degree of capital costs rose from $32 \%$ to $68 \%$ between $1990 / 96$, falling back down to $63 \%$ by 2002 . 
However, the percentage of countries offering residential electricity service at tariffs lower than operating and maintenance cost fell from $16 \%$ to $0 \%$ over the entire period.

Industrial tariffs tend to be slightly lower than residential tariffs, but follow a similar pattern of evolution. Thus, average residential electricity tariffs in the 19 Latin American countries considered rose from US\$0.07 to US\$0.09 per kilowatt-hour between 1990/96, and back down to US\$0.07 per kilowatt-hour by 2002 . Correspondingly, the percentage of countries recovering some degree of capital costs rose from $74 \%$ to $89 \%$ between $1990 / 96$, falling down to $68 \%$ by 2002 . Furthermore, the percentage of countries offering industrial electricity service at tariffs lower than operating and maintenance cost rose from $5 \%$ to $16 \%$ over the entire period.

Table 5: Real electricity tariff trends in 19 Latin American countries

\begin{tabular}{|l|l|l|l|l|l|l|}
\hline US\$/kWh & \multicolumn{3}{|l|}{ Residential } & \multicolumn{3}{l|}{ Industrial } \\
& 1990 & 1996 & 2002 & 1990 & 1996 & 2002 \\
\hline Average tariffs & & & & & & \\
Argentina & 0.09 & 0.12 & 0.04 & 0.09 & 0.09 & 0.02 \\
Bolivia & 0.07 & 0.08 & 0.06 & 0.07 & 0.09 & 0.04 \\
Brazil & 0.08 & 0.15 & 0.08 & 0.06 & 0.06 & 0.04 \\
Chile & 0.14 & 0.15 & 0.08 & 0.08 & 0.08 & 0.06 \\
Colombia & 0.04 & 0.05 & 0.07 & 0.07 & 0.10 & 0.06 \\
Costa Rica & 0.06 & 0.08 & 0.06 & 0.08 & 0.11 & 0.07 \\
Dominican Republic & 0.07 & 0.11 & 0.10 & 0.11 & 0.13 & 0.10 \\
Ecuador & 0.02 & 0.03 & 0.09 & 0.04 & 0.06 & 0.08 \\
El Salvador & 0.04 & 0.09 & 0.09 & 0.04 & 0.12 & 0.11 \\
Guatemala & 0.05 & 0.08 & 0.08 & 0.07 & 0.11 & 0.07 \\
Honduras & 0.07 & 0.07 & 0.07 & 0.05 & 0.10 & 0.06 \\
Jamaica & 0.18 & 0.15 & 0.16 & 0.12 & 0.12 & 0.11 \\
México & 0.06 & 0.05 & 0.08 & 0.06 & 0.04 & 0.06 \\
Nicaragua & 0.06 & 0.12 & 0.13 & 0.07 & 0.11 & 0.11 \\
Panama & 0.16 & 0.13 & 0.12 & 0.14 & 0.11 & 0.10 \\
Paraguay & 0.06 & 0.07 & 0.05 & 0.04 & 0.06 & 0.03 \\
Peru & 0.02 & 0.16 & 0.11 & 0.08 & 0.06 & 0.07 \\
Uruguay & 0.11 & 0.17 & 0.10 & 0.08 & 0.09 & 0.05 \\
Venezuela & 0.02 & 0.02 & 0.06 & 0.02 & 0.02 & 0.03 \\
& & & & & & \\
Average & 0.07 & 0.10 & 0.09 & 0.07 & 0.09 & 0.07 \\
Median & 0.06 & 0.09 & 0.08 & 0.07 & 0.09 & 0.06 \\
Minimum & 0.02 & 0.02 & 0.04 & 0.02 & 0.02 & 0.02 \\
Maximum & 0.18 & 0.16 & 0.16 & 0.14 & 0.13 & 0.11 \\
& & & & & & \\
\hline Cost recovery (\%) & & & & & & \\
Partial capital costs & 32 & 68 & 63 & 74 & 89 & 68 \\
Partial O\&M costs & 52 & 21 & 37 & 21 & 6 & 16 \\
Nil & 16 & 11 & 0 & 5 & 5 & 16 \\
& & & & & & \\
\hline
\end{tabular}

Source: OLADE, 2004

Once again, it is interesting to see how current electricity tariffs in Latin America compare with those in other regions (Table 6). The comparisons are based on average national tariff data for a sample of 83 countries. 
Average residential electricity tariffs in OECD countries currently stand at US\$0.12 per kilowatt-hour, so that more than $80 \%$ of OECD countries have residential tariffs high enough to make a significant contribution towards capital costs. As in the case of water, Latin America has the strongest record on cost recovery of any of the developing regions, with average residential tariffs at US\$0.09 per kilowatt-hour and just over half of countries practicing residential tariffs that make a significant contribution to the recovery of capital costs. These tariffs are about 50\% higher than those observed in other developing regions that typically lie in the US\$0.04-0.06 per kilowatt-hour range.

As before, there is a strong relationship between cost recovery and the income level of the country. Average tariffs rise from around US\$0.05 per kilowatt-hour in low-income countries, to US\$0.06-0.07 per kilowatt-hour in middle-income countries and US\$0.12 per kilowatt-hour in high-income countries. The percentage of utilities whose tariffs make some significant contribution to covering capital costs rises correspondingly from around $25 \%$ in low-income countries to around $30 \%$ in middle-income countries, and $80 \%$ in high-income countries. Once again, it is striking to note that Latin America's performance on cost recovery is above the average for upper-middle-income countries.

Table 6: Overview of average residential electricity tariffs

\begin{tabular}{|c|c|c|c|c|c|c|c|c|c|c|}
\hline & $\begin{array}{l}\text { Mean } \\
\left(\mathrm{US} \$ / \mathrm{m}^{3}\right)\end{array}$ & $\begin{array}{l}\text { Median } \\
\left(\mathrm{US} \$ / \mathrm{m}^{3}\right)\end{array}$ & $\begin{array}{l}\text { Standard } \\
\text { deviation } \\
\left(\mathrm{US} \$ / \mathrm{m}^{3}\right)\end{array}$ & $\begin{array}{l}\text { Rang } \\
\text { (US\$ } \\
\text { Min }\end{array}$ & $\begin{array}{l}3 \text { ) } \\
\text { Max }\end{array}$ & $\begin{array}{l}\text { IQ R } \\
\text { (US\$ } \\
\text { Min }\end{array}$ & $\begin{array}{l}\text { ge } \\
\left.3^{3}\right) \\
\text { Max }\end{array}$ & $\begin{array}{l}\text { Deg } \\
(\%) \\
\text { Nil }\end{array}$ & $\begin{array}{l}\text { of cost } \\
\text { Partial } \\
\text { O\&M }\end{array}$ & $\begin{array}{l}\text { covery } \\
\text { Partial } \\
\text { capital }\end{array}$ \\
\hline Global & 0.08 & 0.07 & 0.04 & 0.01 & 0.21 & 0.05 & 0.10 & 15 & 44 & 41 \\
\hline $\begin{array}{l}\text { By income } \\
\text { HIC } \\
\text { UMIC } \\
\text { LMIC } \\
\text { LIC }\end{array}$ & $\begin{array}{l}0.12 \\
0.07 \\
0.06 \\
0.05\end{array}$ & $\begin{array}{l}0.11 \\
0.06 \\
0.05 \\
0.05\end{array}$ & $\begin{array}{l}0.04 \\
0.03 \\
0.03 \\
0.03\end{array}$ & $\begin{array}{l}0.06 \\
0.04 \\
0.03 \\
0.01\end{array}$ & $\begin{array}{l}0.21 \\
0.14 \\
0.14 \\
0.13\end{array}$ & $\begin{array}{l}0.09 \\
0.05 \\
0.04 \\
0.04\end{array}$ & $\begin{array}{l}0.13 \\
0.09 \\
0.08 \\
0.06\end{array}$ & $\begin{array}{l}0 \\
0 \\
27 \\
31\end{array}$ & $\begin{array}{l}17 \\
71 \\
50 \\
44\end{array}$ & $\begin{array}{l}83 \\
29 \\
23 \\
25\end{array}$ \\
\hline $\begin{array}{l}\text { By region } \\
\text { OECD } \\
\text { LAC } \\
\text { ECA } \\
\text { EAP } \\
\text { SSA } \\
\text { SAS }\end{array}$ & $\begin{array}{l}0.12 \\
0.09 \\
0.06 \\
0.05 \\
0.05 \\
0.04\end{array}$ & $\begin{array}{l}0.11 \\
0.09 \\
0.04 \\
0.05 \\
0.06 \\
0.04\end{array}$ & $\begin{array}{l}0.04 \\
0.03 \\
0.03 \\
0.02 \\
0.02 \\
0.01\end{array}$ & $\begin{array}{l}0.06 \\
0.05 \\
0.02 \\
0.01 \\
0.03 \\
0.04\end{array}$ & $\begin{array}{l}0.21 \\
0.14 \\
0.14 \\
0.08 \\
0.08 \\
0.05\end{array}$ & $\begin{array}{l}0.09 \\
0.06 \\
0.04 \\
0.04 \\
0.04 \\
0.04\end{array}$ & $\begin{array}{l}0.13 \\
0.10 \\
0.08 \\
0.06 \\
0.06 \\
0.05\end{array}$ & $\begin{array}{l}0 \\
0 \\
31 \\
29 \\
29 \\
33\end{array}$ & $\begin{array}{l}17 \\
47 \\
38 \\
65 \\
71 \\
67\end{array}$ & $\begin{array}{l}83 \\
53 \\
31 \\
6 \\
0 \\
0\end{array}$ \\
\hline
\end{tabular}

Sources: OECD 2004, ERRA 2004, EIA 2004, OLADE 2004, Estache and Gassner 2004, UN-ESCAP 2004.

Notes: Data drawn from 84 countries worldwide, broken down as follows OECD (23), LAC (19), ECA(18), SSA(13), EAP (8), SAS (3)

Comparing the results presented in Table 6 for electricity, with those presented in Table 3 for water, it is evident that — while the same general patterns hold— the absolute extent of cost recovery is far higher for electricity services across the income spectrum. Thus, while $85 \%$ of countries (and $69 \%$ of low-income countries) achieve some degree of cost recovery for electricity, only $60 \%$ of utilities (and 12\% of low-income utilities) achieve some degree of cost recovery for water. Moreover, average tariffs for electricity in high- 
income countries are around twice as high as those in low-income countries, while average tariffs for water in high-income countries are around nine times as high as those in low-income countries.

In summary, residential electricity tariffs in Latin America have not risen very substantially on average over the period 1990/02; tariff increases tended to be more pronounced in the period 1990/96 followed by a subsequent decline. Overall, these increases have been more modest than those observed in other developing regions. Nonetheless, the percentage of power utilities whose tariffs make a significant contribution to capital costs has virtually doubled over the decade, although it is still less than two thirds of the total. Moreover, the percentage of utilities whose tariffs do not even cover operating and maintenance costs has also fallen substantially. In addition, Latin America has the highest average residential electricity tariffs of any developing region, exceeding that of upper-middle-income countries as a whole. However, at US $\$ 0.09$ per kilowatt-hour they are still only $75 \%$ of those applied in OECD countries, and the extent of cost recovery also lags behind that observed in industrialized countries.

\section{The Problem of Affordability}

One of the most common reasons cited for the difficulty in reaching cost recovery tariffs for water and electricity services is the problem of affordability among residential customers, and low income households particularly. Nevertheless, the concept of affordability is seldom rigorously defined, nor is it often evaluated in empirical terms.

The purpose of this section is to estimate what percentage of the population may experience genuine problems of affordability for water and electricity services when these are charged at cost recovery prices. In order to make this assessment, the cost of purchasing a subsistence allowance of water and electricity services is estimated both at current tariff levels and at cost recovery benchmark levels.

Given the variations that exist in subsistence consumption, depending on climatic conditions and cultural norms, both an upper and lower bound estimate are given. In the case of water, the lower bound is based on a consumption level of around 50 liters per capita per day for a household of five, which according to the World Health Organization is around the minimum needed for basic hygiene. The upper bound is based on a consumption level of around 100 liters per capita per day for a household of five and is a more typical level of modest use in urbanized settings. In the case of electricity, the lower bound is based on a household with a few light bulbs and a small radio, while the upper bound is based on a household with a few light bulbs, plus a modest refrigerator and a small television.

Notwithstanding the width of these ranges, the bottom line is that households will require a sum of the order of US\$4-13 per month in order to meet their basic needs for each of these services (Table 7). 
Table 7: Reference level for cost of subsistence consumption (US\$/m)

\begin{tabular}{|lll|lll|}
\hline Water & $\begin{array}{l}\text { Current } \\
\text { LAC tariff } \\
\text { US } \$ 0.40 / \mathrm{m}^{3}\end{array}$ & $\begin{array}{l}\text { Cost recovery } \\
\text { tariff } \\
\text { US } \$ 0.80 / \mathrm{m}^{3}\end{array}$ & Electricity & $\begin{array}{l}\text { Current } \\
\text { LAC tariff } \\
\text { US } \$ 0.09 / \mathrm{kWh}\end{array}$ & $\begin{array}{l}\text { Cost recovery } \\
\text { tariff } \\
\text { US } \$ 0.09 / \mathrm{kWh}\end{array}$ \\
\hline $\begin{array}{l}\text { Lower bound } \\
8 \mathrm{~m}^{3} / \mathrm{m}\end{array}$ & 3.20 & 6.40 & $\begin{array}{l}\text { Lower bound } \\
40 \mathrm{kWh} / \mathrm{m}\end{array}$ & 3.60 & 3.60 \\
\hline $\begin{array}{l}\text { Upper bound } \\
16 \mathrm{~m}^{3} / \mathrm{m}\end{array}$ & 6.40 & 12.80 & $\begin{array}{l}\text { Upper bound } \\
120 \mathrm{kWh} / \mathrm{m}\end{array}$ & 10.80 & 10.80 \\
\hline
\end{tabular}

In order to understand how much of a burden such charges might represent, data are collected on the distribution of income in 32 countries (19 from Latin America, 8 from Africa, and 4 from East Asia, plus India). Interest focuses on the distribution of household income, rather than the distribution of personal income as is more typically studied, because household income is the relevant budgetary constraint for utility services. Due to constraints in data availability household income data are used for India and Latin America, while household expenditure data are used for Africa and East Asia. In general, expenditure is thought to be a more reliable indicator of household welfare than income. Given that expenditure is known to be more equitably distributed than income, statistics based on income may tend to over-state the affordability problem faced by low income households relative to statistics based on expenditure.

The data are used to calculate average household income (expenditure) at each level of the income (expenditure) distribution, which can then be compared against the cost recovery benchmark for utility prices in order to determine the extent to which these are affordable. The analysis focuses entirely on the urban income distribution, since utility services are mainly prevalent in urban areas. The methodology used to calculate average household income (expenditure) in comparable dollar terms across countries is described in greater detail in Appendix 2.

The analysis is repeated both in US dollar and international dollar terms reflecting purchasing power parity. The former is more appropriate to the extent that water and utility services are regarded as traded goods, while the latter is more appropriate to the extent that they are regarded as non-tradable goods. In reality, the cost structure of electricity and water services comprises both tradable and non-tradable components. In practice, the exact balance between the two is likely to depend on the size and income level of the country. Large middle-income countries may have the capacity to produce many of the manufactured inputs for water and electricity services, whereas smaller lower-income countries will often need to import them. In addition, other things being equal, water services (due to their greater reliance on public works and lesser reliance on sophisticated mechanical equipment) would tend to have a lower share of imported items in the overall cost structure. In summary, it would appear that water services in large middle-income countries are close to being entirely locally produced. On the other hand, electricity services in smaller lower-income countries are close to being entirely imported. Other cases lie somewhere in between. 
While there is no objective basis for determining whether or not a particular level of expenditure on utility services is affordable, the threshold of 5\% of income as a reasonable limit for expenditure on water is often used in Latin America. Moreover, analysis of household survey data suggest that the poorest households rarely spend more than $5 \%$ of income on water (Figure 5). In the case of electricity, there is no comparable threshold in widespread usage, however analysis of household survey data suggest that poor households rarely spend more than $6-8 \%$ of income on electricity (Figure 6).

Figure 5: Household survey evidence on water expenditure by quintile

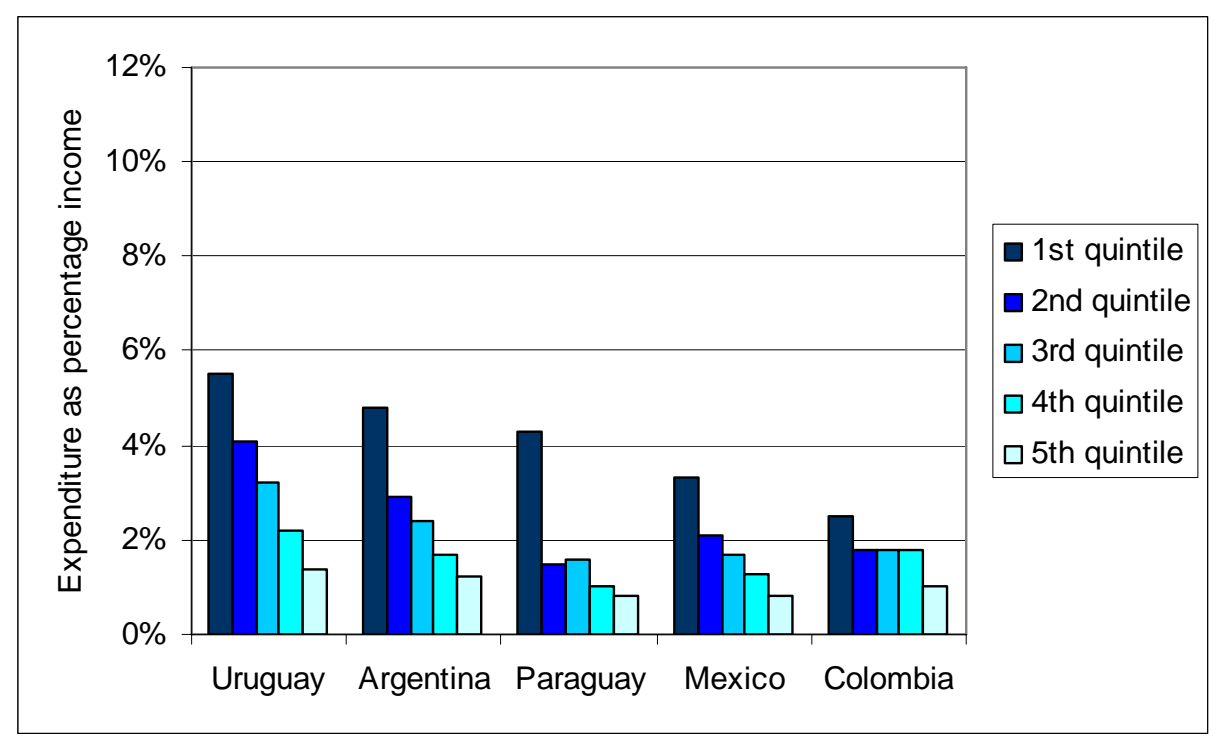

Source: Own elaboration from LSMS household survey data

Figure 6: Household survey evidence on electricity expenditure by quintile

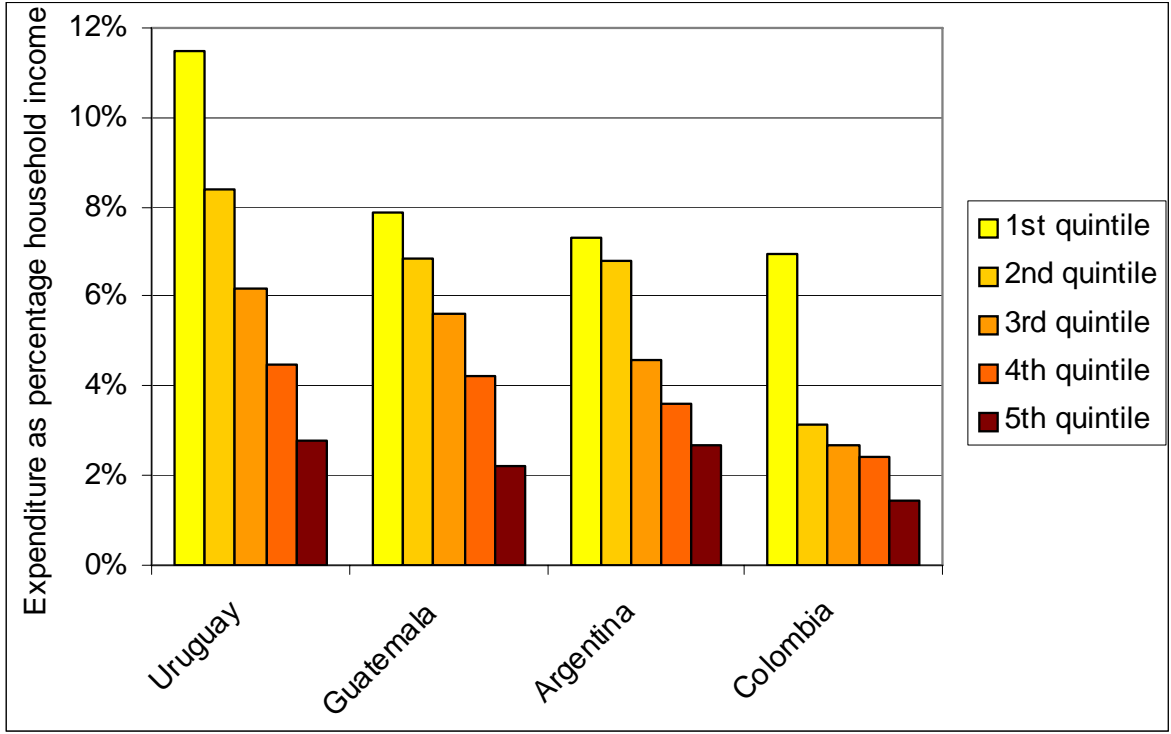

Source: Own elaboration from LSMS household survey data 
On this basis, it is possible to calculate the percentage of the urban population within each Latin American country that would need to spend more than 5\% of their income in order to purchase a subsistence block of water or electricity at different cost levels in current US\$ terms (Figure 7a). The results show a wide dispersion of outcomes across countries. In low-income countries— such as Bolivia, Honduras and Nicaragua —utility bills of around US $\$ 10$ per month already represent a substantial burden for $30-50 \%$ of urban households. In lower-middle-income countries - such as Argentina, Brazil and Colombia - utility bills of around US\$15 per month start to represent an affordability problem for around $30 \%$ of urban households. Finally, in upper-middle-income countries - such as Mexico and Venezuela-less than 10\% of the population would appear to face genuine problems of affordability at any of the levels considered. However, when the same exercise is repeated in PPP terms, utility bills in the range US\$10-15 per month appear to be affordable for the vast majority of the population in all of the countries considered (Figure $7 \mathrm{~b}$ )

A similar exercise is performed considering what percentage of the average income level of each quintile of the regional income distribution would be absorbed when utility bills are set at a variety of levels (Figures 8a,b). The results show that when bills are expressed in current US\$ terms, affordability problems are confined only to the first quintile of the regional income distribution once utility bills exceed the US\$10 per month threshold. However, when bills are expressed in PPP terms, there do not appear to be major affordability problems, even for households in the first income quintile.

It is interesting to compare the situation in Latin America with that of other regions with greater prevalence of poverty (Figures 9a,b). Once again, this is done by calculating the percentage of urban households that would need to spend more than $5 \%$ of income (expenditure) on utilities if bills were set at a range of different levels. When expressed in current US\$ terms, the results show that the affordability problem is very much more severe in Asia and Sub-Saharan Africa than in Latin America. Whereas only $10 \%$ of Latin American households would face affordability problems with utility bills at US\$10 per month, around $35 \%$ of East Asian households and $55 \%$ of Indian and African households would face affordability problems at the same reference level of utility bills. Nevertheless, when the same exercise is repeated in PPP terms, the extent of the affordability problem is reduced and the divergences between regions attenuated. Thus, even monthly utility bills approaching US\$20 in PPP terms would only create problems for the bottom quintile of the distribution in Asia and Africa.

Clearly the extent to which the cost of providing utility services is predominantly driven by local or international costs makes a huge difference to the conclusions regarding the affordability of utility services. In Latin American countries, where the provision of utility services is largely driven by local costs, there does not appear to be a major affordability problem. However, in countries where the cost structure is largely international, there does appear to be a significant affordability issue affecting the bottom $30-50 \%$ of the urban income distribution. In either case, affordability problems in Latin America are much more limited compared to those found in other regions of the world with greater prevalence of poverty. 
Figure 7a: Urban households facing affordability problems by country (current US\$)

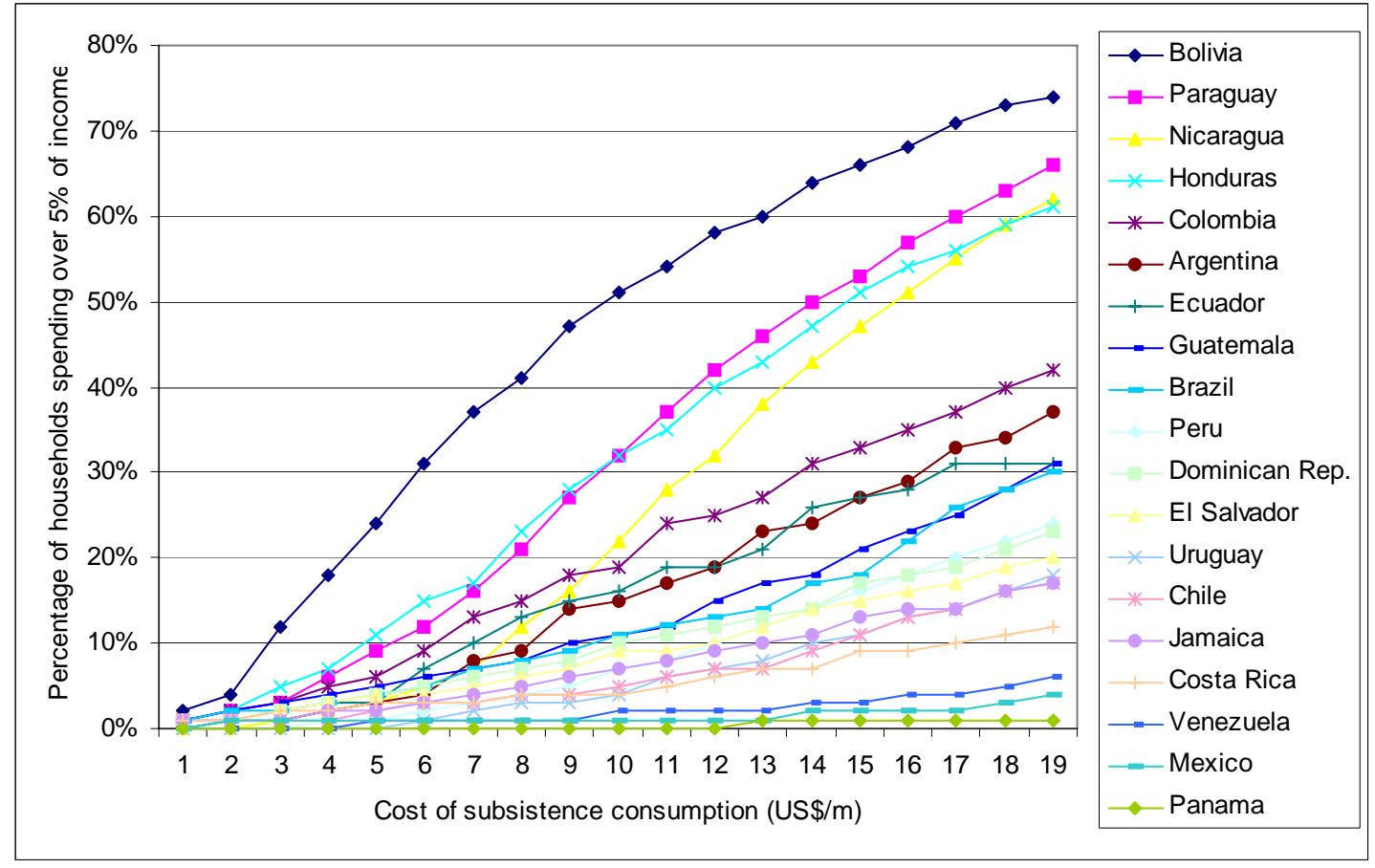

Source: Own elaboration from LSMS household survey data

\section{Figure 7b: Urban households facing affordability problems by country (PPP)}

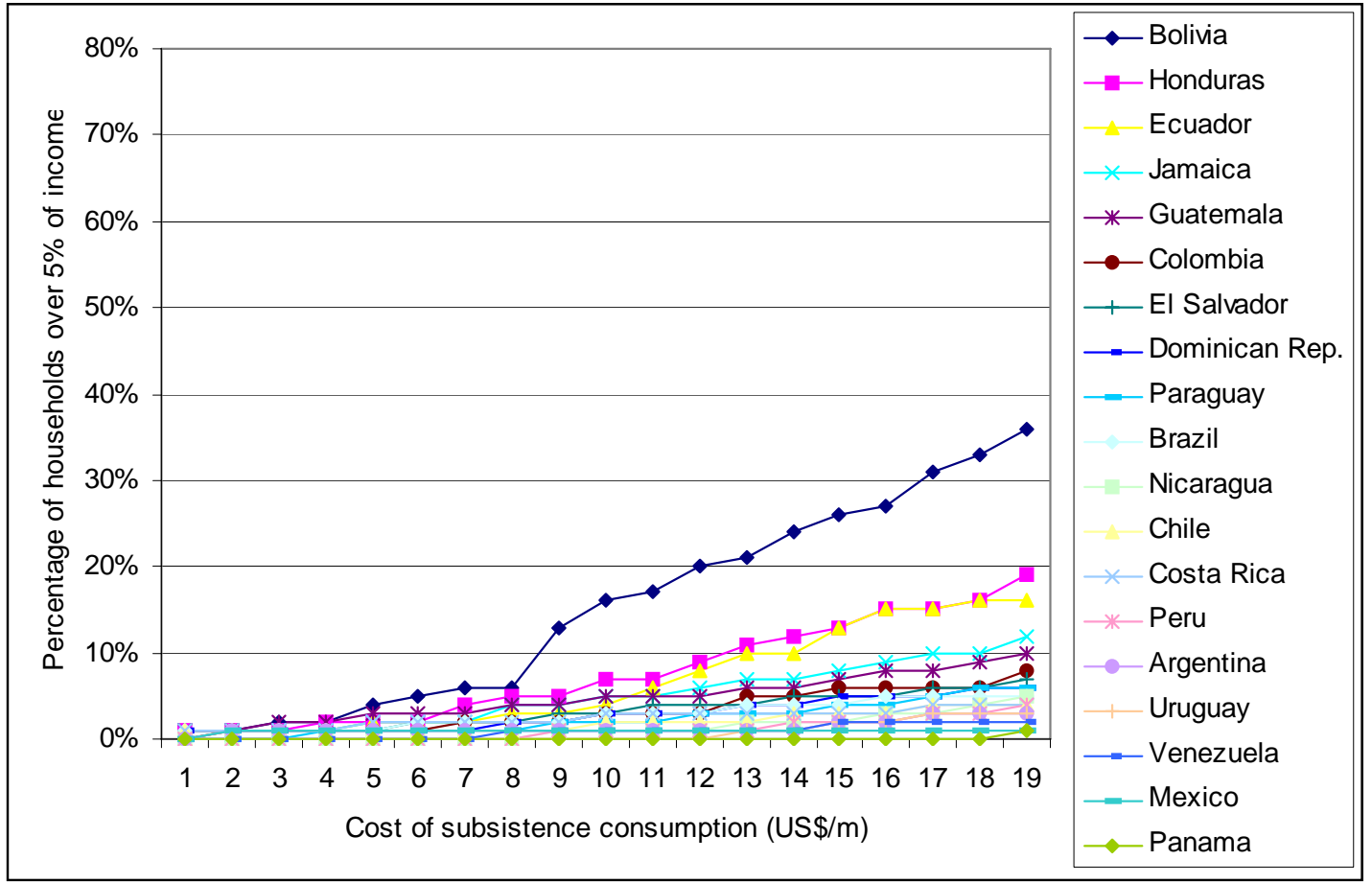

Source: Own elaboration from LSMS household survey data 
Figure 8a: Income share on subsistence consumption by LAC urban quintiles (current US\$)

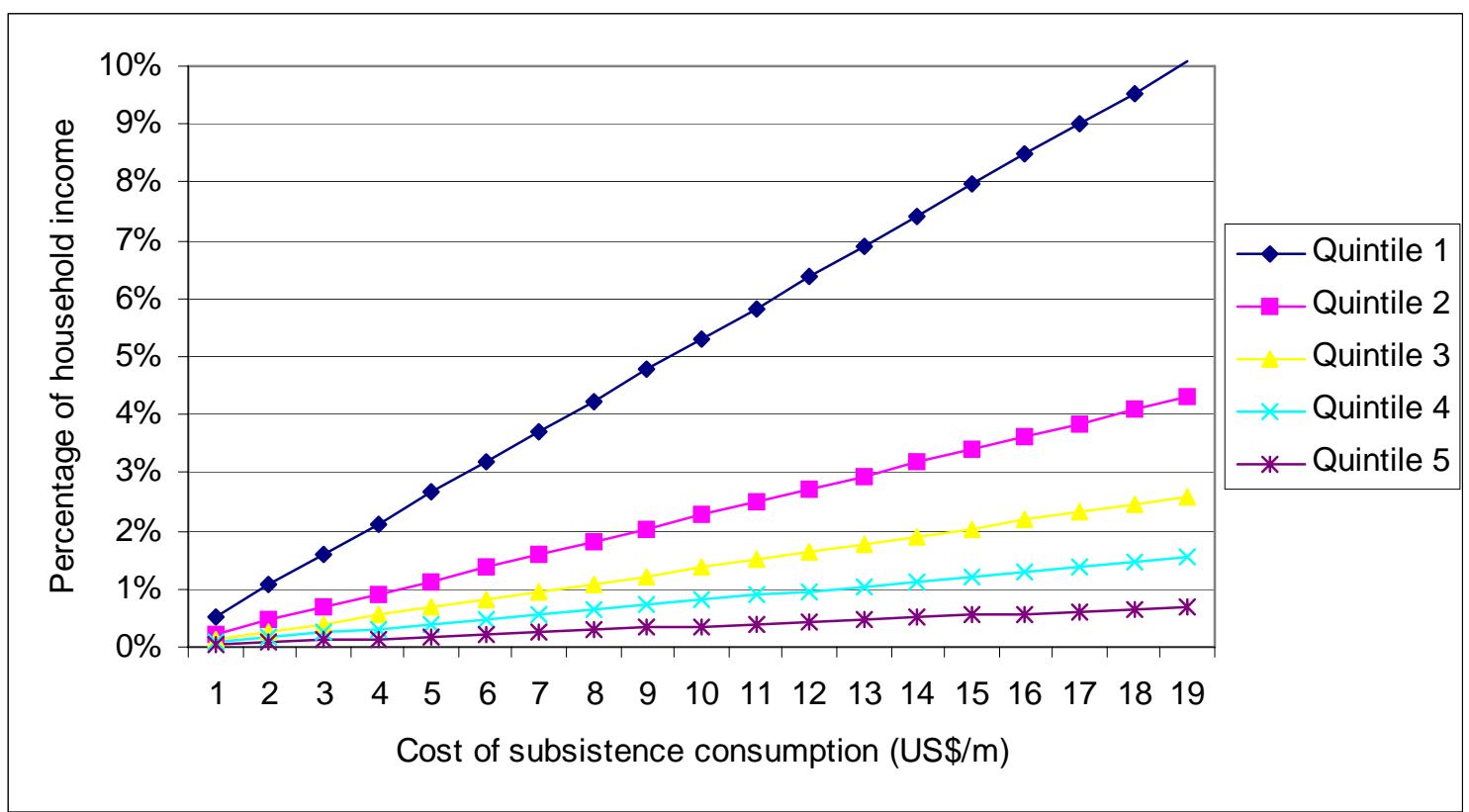

Source: Own elaboration from LSMS household survey data

Figure 8b: Income share on subsistence consumption by LAC urban quintiles (PPP)

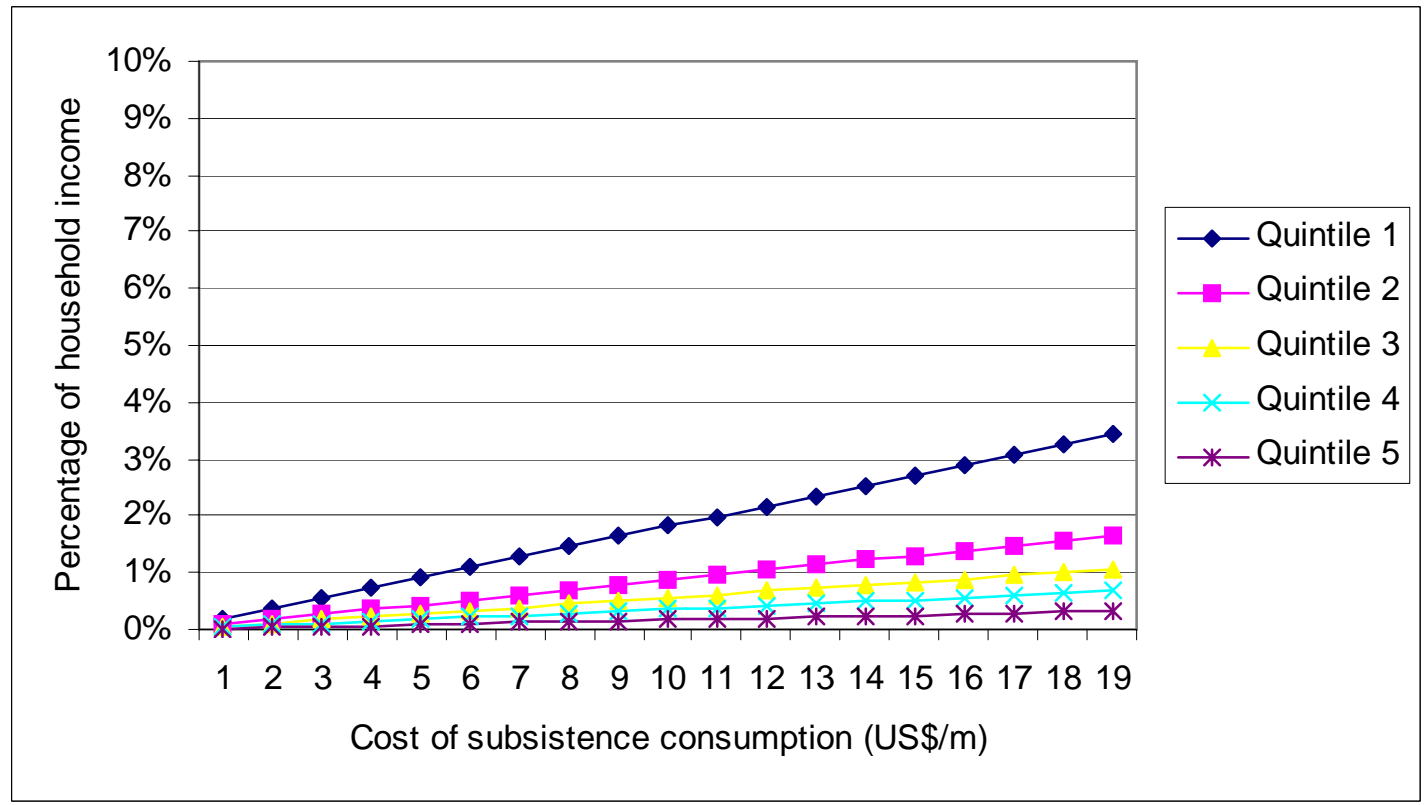

Source: Own elaboration from LSMS household survey data 
Figure 9a: Urban households facing affordability problems by region (current US\$)

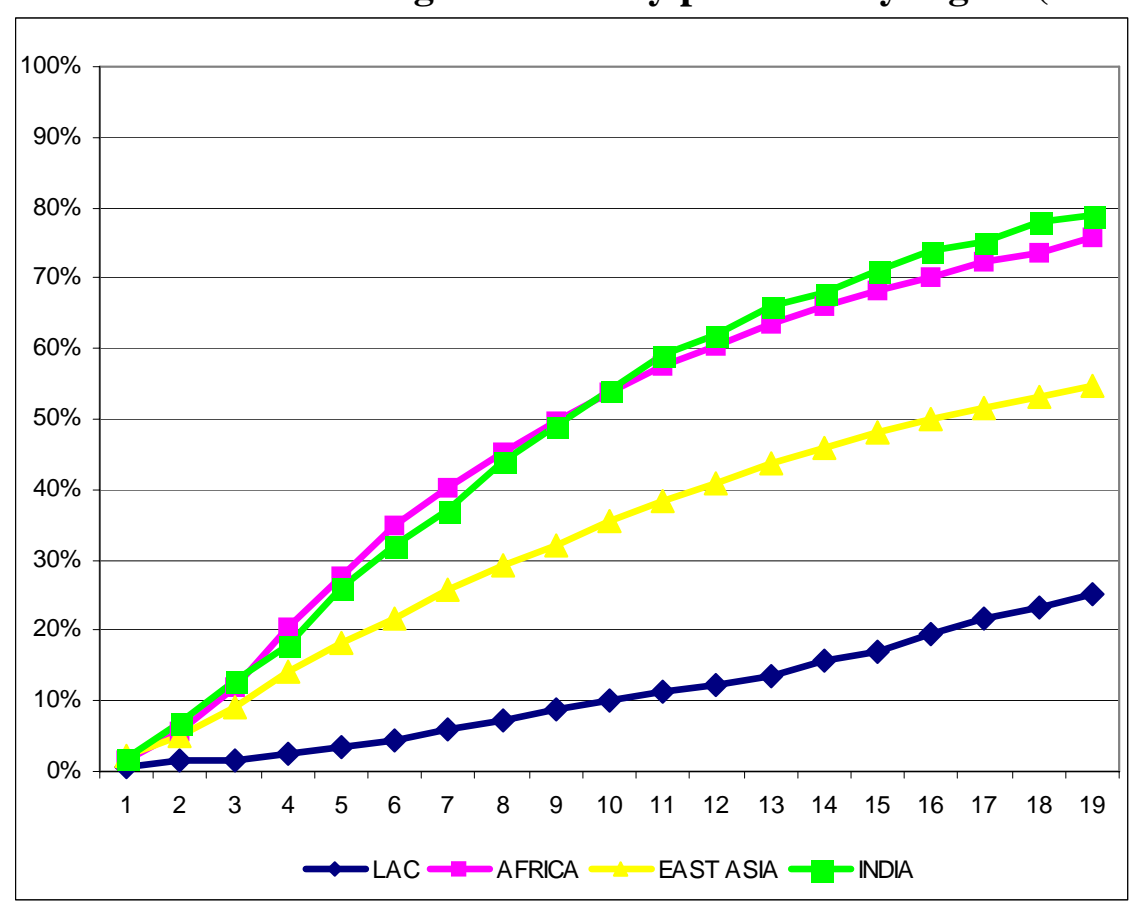

Source: Own elaboration from LSMS household survey data

Note: Data from India and Latin America are based on household income, while data on Africa and East Asia are based on household expenditure, as a result the two groups are not directly comparable.

Figure 9b: Urban households facing affordability problems by region (PPP)

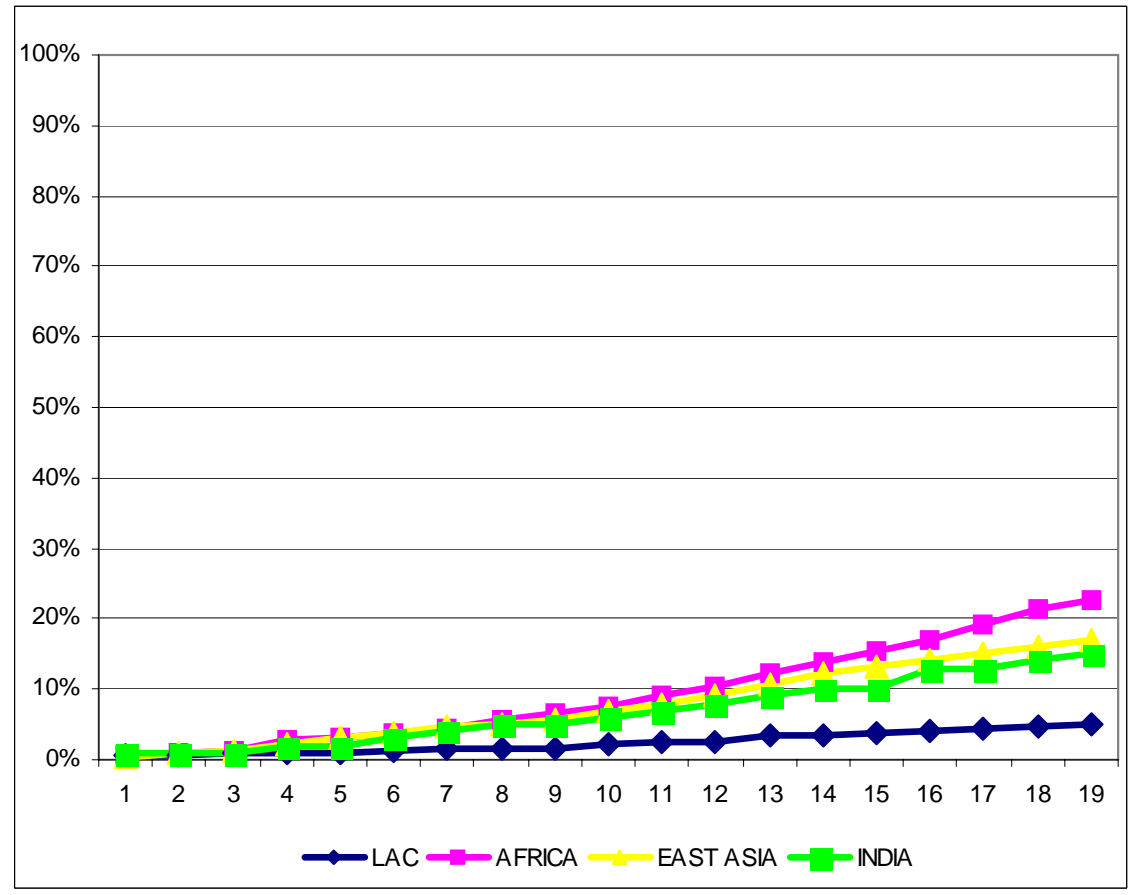

Source: Own elaboration from LSMS household survey data 
Note: Data from India and Latin America are based on household income, while data on Africa and East Asia are based on household expenditure, as a result the two groups are not directly comparable.

A final way to look at this issue is to estimate the impact of increasing service tariffs towards cost recovery levels on the incidence of poverty. By raising the cost of meeting an essential service, such tariff increases would effectively reduce the real income of the population, thereby bringing more people under the poverty line, or deepening the poverty of those already under the poverty line.

A number of scenarios are considered for increasing utility bills. The first scenario raises the monthly bill from US\$3 to US\$6 per month, the second scenario raises the monthly bill from US\$6 to US\$12 per month, while the third scenario raises the monthly bill from US\$1 to US\$12 per month. The first two scenarios correspond to the kind of tariff increases that might be required in Latin America (recall Table 7). The third scenario is more relevant to some low-income countries that would need to raise utility bills by an order of magnitude in order to reach cost recovery levels (recall Tables 3 and 6).

In each of these cases, the data on household income (expenditure) distribution is used to calculate the percentage increase in three poverty measures: the headcount ratio $(\mathrm{HC})$, which measures the percentage of the population under the poverty line; the poverty gap (PG), which measures the average percentage deviation of the income (expenditure) of those under the poverty line from the level represented by the poverty line; and the FGT index, which measures the average squared percentage deviation of the income (expenditure) of those under the poverty line from the level represented by the poverty line. In all cases, an ordinal poverty line is used, and is determined at the income (or expenditure) level of the $40^{\text {th }}$ percentile of the income (expenditure) distribution in each region prior to the tariff changes. The poverty impact is calculated as though all households had access to the service. This is manifestly not the case. However, such a calculation is nonetheless valuable in determining whether services would remain affordable to newly connecting households at cost recovery prices. Further methodological details are provided in Appendix 2.

The results show that doubling utility bills from US\$3 to US\$6 or US\$6 to US\$12 does not have a major impact on poverty indices across Latin America, Asia or Africa (Table 8). The exceptions are countries such as Bolivia and Guatemala, where such policies could add 2 percentage points to the headcount poverty rate. However, with increases from US\$1 to US\$12 per month, the poverty impact is quite large across all regions, but particularly in Asia and Africa. The headcount ratio increases by 2 to 3 percentage points in Latin America, 3 to 5 percentage points in Asia, and four to seven percentage points in Africa. The poverty gap and FGT indices also increase substantially, particularly in Africa. These findings suggest that there is still significant scope for progress towards cost recovery in middle-income countries where tariffs are already reasonably high, without major impact on poverty. However, in low-income countries starting from very low baseline tariffs, the social consequences of any transition towards cost recovery would appear to be very large.

In summary, based on a 5\% affordability threshold, cost recovery tariffs would represent affordability problems only for the poorest $20 \%$ of households in Latin America. 
However, in the region's lower-income countries (Bolivia, Honduras, Nicaragua, Paraguay), reaching cost recovery tariffs would represent a significant affordability problem for around half of the population. Affordability problems are much more serious in India and Africa where around $70 \%$ of households could be expected to face difficulties in paying full cost recovery tariffs. Nevertheless, the extent of the affordability problem reduces substantially when incomes are measured in purchasing power parity terms. Finally, raising tariffs to cost recovery levels is not found to have any significant impact on the prevalence of poverty in middle-income countries, which have already made some progress towards cost recovery. However, in low-income countries where tenfold tariff increases may be required to reach cost recovery levels, such a policy would have a substantial adverse impact on poverty.

Table 8: Poverty impact of raising tariffs to cost recovery levels

\begin{tabular}{|c|c|c|c|c|c|c|c|c|c|}
\hline & \multicolumn{3}{|c|}{ From US\$3 to US\$6 } & \multicolumn{3}{|c|}{ From US\$6 to US\$12 } & \multicolumn{3}{|c|}{ From US\$1 to US\$12 } \\
\hline & $\Delta \mathrm{HC}$ & $\Delta \mathrm{PG}$ & $\Delta \mathrm{FGT}$ & $\Delta \mathrm{HC}$ & $\Delta \mathrm{PG}$ & $\Delta \mathrm{FGT}$ & $\Delta \mathrm{HC}$ & $\Delta \mathrm{PG}$ & $\Delta \mathrm{FGT}$ \\
\hline Latin America & & & & & & & & & \\
\hline Argentina & 0.0 & 0.1 & 0.1 & 0.0 & 0.1 & 0.1 & 1.0 & 1.1 & 0.8 \\
\hline Bolivia & 2.0 & 0.3 & 0.3 & 2.0 & 0.4 & 0.3 & 2.0 & 2.9 & 2.3 \\
\hline Brazil & 0.0 & 0.1 & 0.1 & 0.0 & 0.1 & 0.1 & 0.0 & 1.1 & 0.9 \\
\hline Chile & 0.0 & 0.1 & 0.1 & 0.0 & 0.1 & 0.1 & 1.0 & 0.7 & 0.5 \\
\hline Colombia & 0.0 & 0.1 & 0.1 & 0.0 & 0.2 & 0.1 & 0.0 & 1.5 & 1.2 \\
\hline Costa Rica & 1.0 & 0.1 & 0.1 & 1.0 & 0.1 & 0.1 & 2.0 & 0.6 & 0.6 \\
\hline Dominican Rep. & 1.0 & 0.1 & 0.1 & 1.0 & 0.2 & 0.2 & 1.0 & 1.1 & 1.1 \\
\hline Ecuador & 1.0 & 0.2 & 0.2 & 1.0 & 0.2 & 0.2 & 2.0 & 1.1 & 1.0 \\
\hline El Salvador & 1.0 & 0.2 & 0.2 & 1.0 & 0.2 & 0.2 & 0.0 & 1.1 & 1.1 \\
\hline Guatemala & 2.0 & 0.2 & 0.1 & 2.0 & 0.2 & 0.2 & 0.0 & 1.1 & 0.9 \\
\hline Honduras & 0.0 & 0.2 & 0.2 & 0.0 & 0.3 & 0.3 & 2.0 & 2.1 & 1.8 \\
\hline Jamaica & 0.0 & 0.2 & 0.2 & 0.0 & 0.2 & 0.2 & 0.0 & 0.7 & 0.7 \\
\hline Mexico & 0.0 & 0.1 & 0.1 & 0.0 & 0.1 & 0.1 & 0.0 & 0.3 & 0.3 \\
\hline Nicaragua & 1.0 & 0.2 & 0.2 & 1.0 & 0.3 & 0.2 & 3.0 & 2.6 & 1.9 \\
\hline Panama & 0.0 & 0.1 & 0.1 & 0.0 & 0.2 & 0.1 & 1.0 & 0.6 & 0.5 \\
\hline Paraguay & 1.0 & 0.1 & 0.1 & 1.0 & 0.2 & 0.1 & 3.0 & 2.1 & 1.6 \\
\hline Peru & 1.0 & 0.1 & 0.1 & 1.0 & 0.2 & 0.1 & 2.0 & 1.0 & 0.7 \\
\hline Uruguay & 0.0 & 0.1 & 0.1 & 0.0 & 0.2 & 0.1 & 2.0 & 0.9 & 0.6 \\
\hline Venezuela & 0.0 & 0.1 & 0.1 & 0.0 & 0.1 & 0.1 & 1.0 & 0.6 & 0.3 \\
\hline Asia & & & & & & & & & \\
\hline India & 0.0 & 0.2 & 0.2 & 0.0 & 0.3 & 0.3 & 5.0 & 3.5 & 3.1 \\
\hline Indonesia & 1.0 & 0.4 & 0.4 & 1.0 & 0.5 & 0.5 & 5.0 & 4.4 & 3.9 \\
\hline Philippines & 1.0 & 0.1 & 0.1 & 1.0 & 0.2 & 0.1 & 3.0 & 2.1 & 1.5 \\
\hline South Korea & 0.0 & 0.1 & 0.0 & 0.0 & 0.1 & 0.0 & 1.0 & 0.3 & 0.2 \\
\hline Thailand & 1.0 & 0.1 & 0.1 & 1.0 & 0.2 & 0.1 & 3.0 & 1.4 & 0.7 \\
\hline Africa & & & & & & & & & \\
\hline Burkina Faso & 1.0 & 0.4 & 0.4 & 1.0 & 0.5 & 0.5 & 2.0 & 3.8 & 3.7 \\
\hline Cameroon & 1.0 & 0.2 & 0.3 & 1.0 & 0.3 & 0.3 & 1.0 & 2.5 & 2.5 \\
\hline Cape Verde & 1.0 & 0.1 & 0.1 & 1.0 & 0.1 & 0.1 & 0.0 & 1.3 & 1.3 \\
\hline Mauritania & 0.0 & 0.2 & 0.1 & 0.0 & 0.2 & 0.2 & 4.0 & 2.7 & 2.0 \\
\hline Mozambique & 0.0 & 0.4 & 0.2 & 0.0 & 0.5 & 0.3 & 7.0 & 6.0 & 4.3 \\
\hline Rwanda & 0.0 & 0.2 & 0.1 & 0.0 & 0.3 & 0.2 & 7.0 & 4.3 & 2.8 \\
\hline Sao Tome & 0.0 & 0.2 & 0.2 & 0.0 & 0.3 & 0.2 & 4.0 & 3.5 & 2.4 \\
\hline Senegal & 0.0 & 0.2 & 0.1 & 0.0 & 0.2 & 0.2 & 2.0 & 2.0 & 1.4 \\
\hline
\end{tabular}

Source: Own elaboration from LSMS household survey data

Note: All cases showing change of two or more percentage points are highlighted in bold. 


\section{Utilities Social Policy}

The previous sections have highlighted the gap that still remains between residential utility tariffs and full cost recovery. Moreover, it has been shown that within Latin America, genuine affordability problems appear to be confined to those in the bottom quintile of the income distribution, and in the lower income countries that face international prices for water and electricity services. These considerations suggest that, in principle, it should be possible to reconcile the objective of cost recovery and social protection through the application of targeted safety nets for utility services. Social tariff schemes for water and electricity, of diverse kinds, are in fact already widespread in Latin America. This section reviews the available evidence on the design and performance of these social policies, and evaluates the extent to which they contribute towards the reconciliation of economic and social objectives in these sectors.

\section{Water}

The analysis of the water sector is based on a detailed review of the tariff structures of some 17 major water utilities in eight countries drawn from around the region (ADERASA, forthcoming). To complement this general overview, the results of a number of detailed evaluations of existing social tariff schemes are also presented.

By far the most commonplace social policy in the water sector is the Increasing Block Tariff (IBT) structure, whereby consumers are able to access the first consumption block at a concessional rate, and pay increasing prices at the margin for additional blocks of consumption. The IBT offers an implicit social safety net in so much as the first block should provide all families with access to a subsistence level of consumption at below the full economic cost. In theory at least, the IBT should still allow utilities to recover the full costs of service provision by charging above cost on higher blocks of consumption. A well-designed IBT should therefore incorporate a relatively small first block, that genuinely relates to subsistence consumption needs. Thereafter, the gradient between marginal tariff and consumption should be steep enough to allow prices to reach cost recovery levels within a normal range of consumption.

IBTs are almost universal among the 17 Latin American water utilities surveyed in this study. Analysis of these tariff structures suggests that there are a number of common problems with their design (Table 9).

First, the size of the subsistence block ranges from 15-40 cubic meters per month, with an average value of 25 cubic meters per month. This value is relatively high, both in relation to the average residential consumption of 20 cubic meters per month in most of these cities, and to benchmark levels of subsistence consumption of 8-16 cubic meters per 
month. ${ }^{3}$ The implication of this is that a very high percentage of total residential consumption benefits from these concessional 'subsistence' rates.

Table 9: Overview of residential water tariff structures

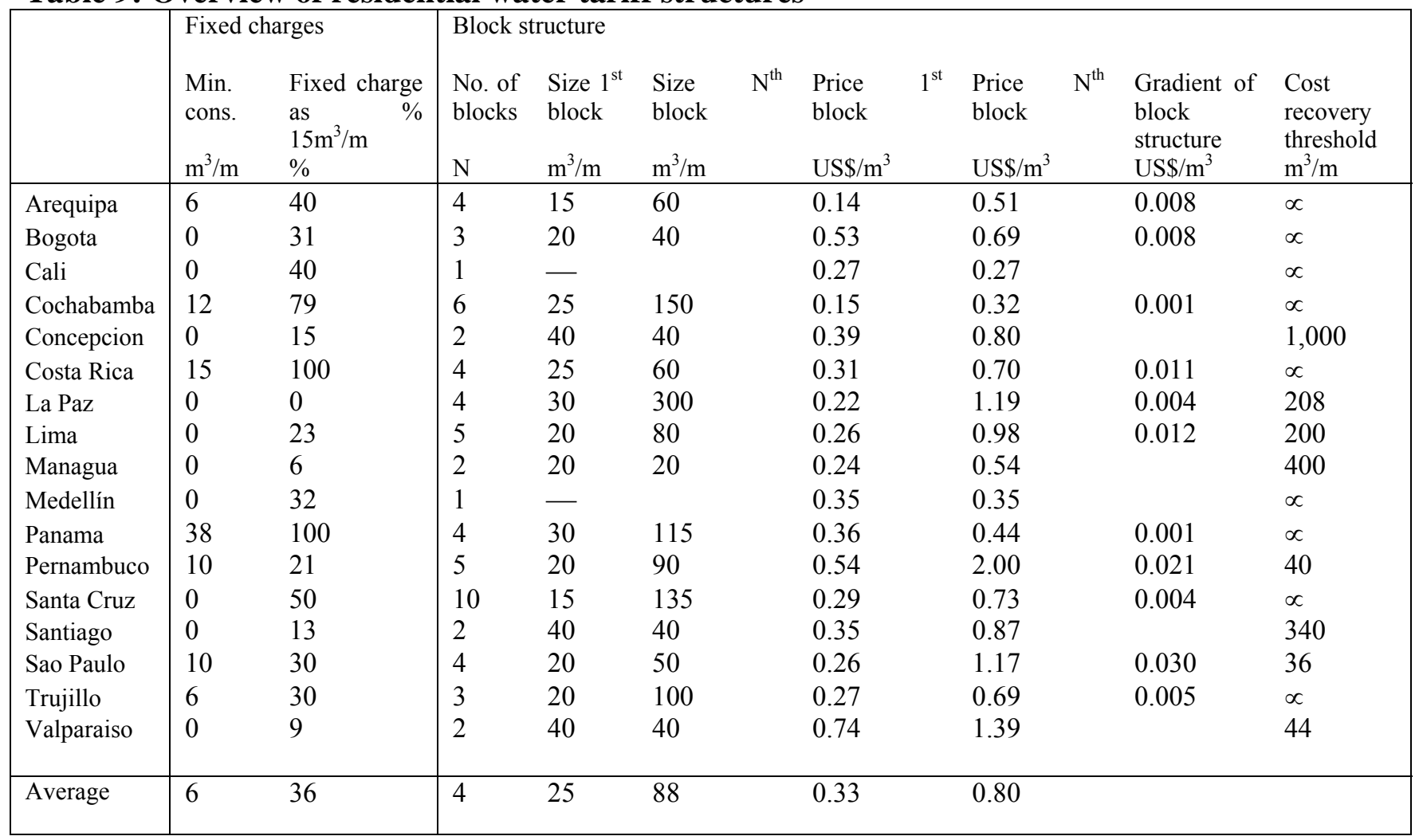

Source: Adapted from ADERASA, forthcoming

Second, the gradient of these tariff structures is generally very flat. As a result, the average tariff only reaches levels commensurate with the full average cost of service provision (of around US $\$ 0.80$ per cubic meter) at extremely high rates of consumption amounting to several hundred cubic meters per month in most cases. Indeed, in $53 \%$ of the utilities considered that tariff structure was such that the average tariff never rises to the cost recovery benchmark level, however much is consumed. What this means is that these IBTs effectively subsidize the totality of residential water use.

Third, around $40 \%$ of the utilities analyzed incorporate minimum consumption thresholds into their tariff structures. This means that any customer consuming up to the threshold level pays the same fixed charge, and volumetric rates are only charged on consumption in excess of the threshold. As a result, customers using less than the minimum amount face very high average tariffs, with the magnitude of the tariffs being inversely related to the level of consumption. Given that the average value of the threshold is 14 cubic meters

\footnotetext{
${ }^{3}$ This estimate is based on a household of five people consuming 50 liters per capita per day that is considered to be the minimum requirement to sustain human health, or alternatively 100 liters per capita per day equivalent to a modest level of consumption in urban areas.
} 
per month, which is to say $70 \%$ of the average consumption level, this problem affects a significant percentage of consumers.

The whole efficacy of IBT structures as income redistribution mechanisms hinges on the hypothesis that water consumption is well correlated with household income. However, this hypothesis has rarely been put to an empirical test. Figure 10 summarizes data on average water consumption by income quintile for eight Latin American utilities. In twothirds of these cases, the variation between the water consumption of the top and bottom quintiles of the income distribution is very weak, no more than $20 \%$ in all, and in some instances the top quintile actually consumes less water than the bottom quintile (Figure 11). However, in other cases such as Paraguay and Colombia, the top income quintile consumes around twice as much as the bottom quintile.

\section{Figure 10: Average monthly water consumption by quintile}

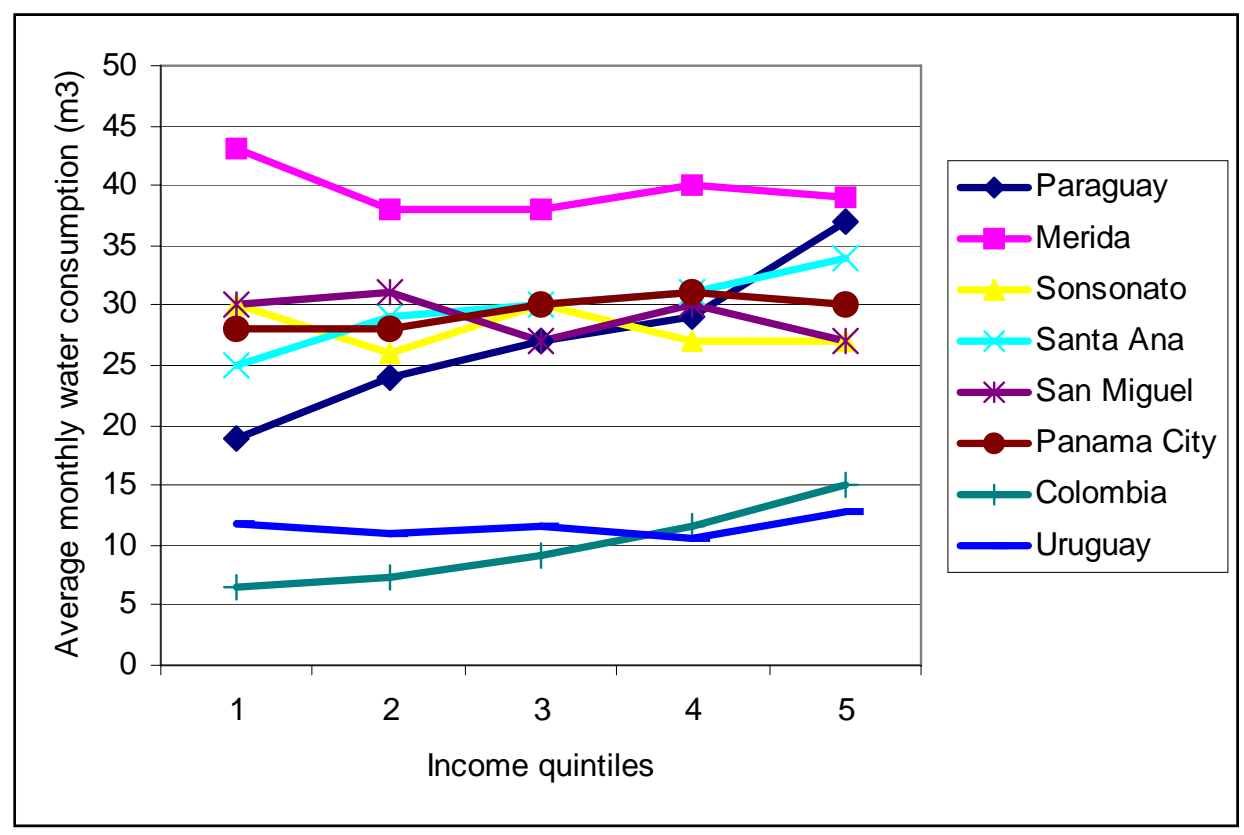

Source: Own elaboration from LSMS household survey data 
Figure 11: Index of relative monthly water consumption by quintile

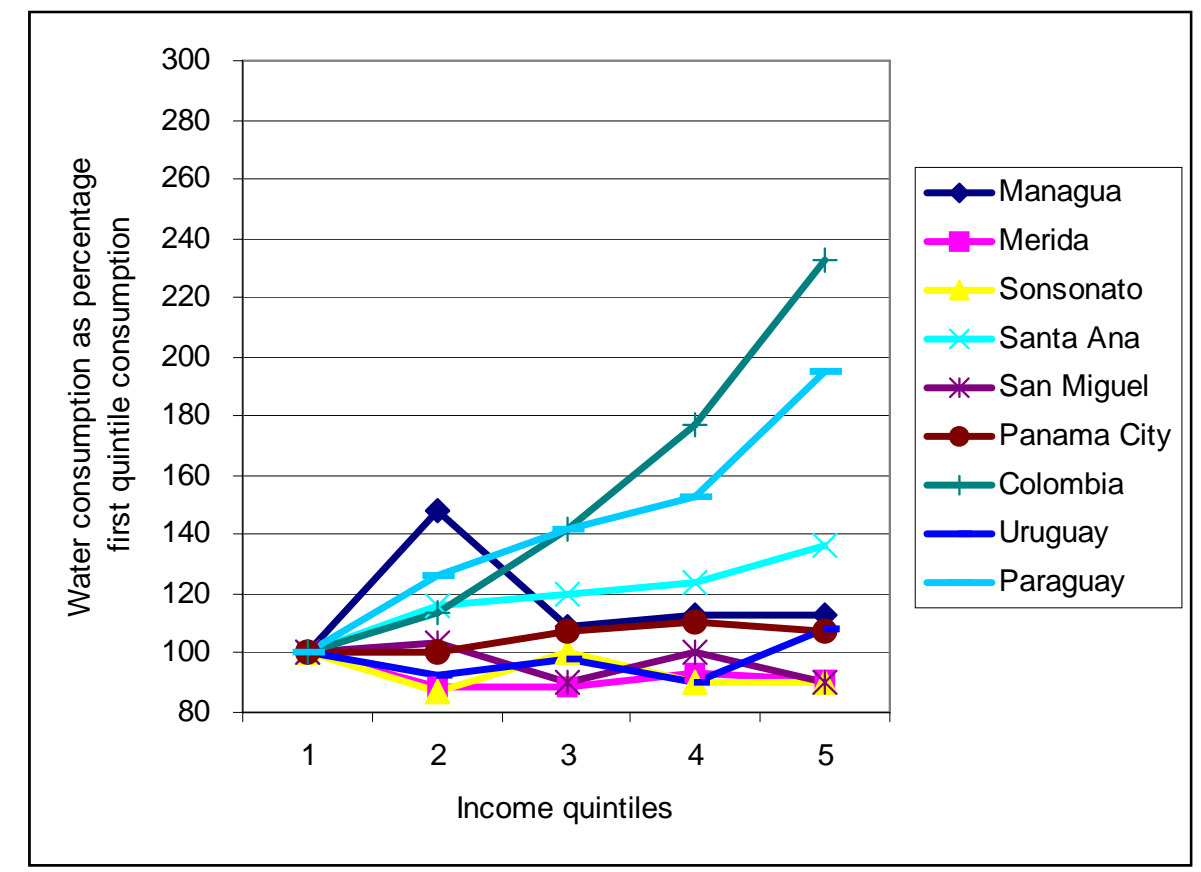

Source: Own elaboration from LSMS household survey data

There are a number of plausible explanations as to why the relationship between income and water consumption might be relatively flat. One is that family sizes tend to be inversely related to income. In Uruguay, for example, bottom quintile households have low per capita water consumption ( 2.6 cubic meters per month) but a large number of family members (4.6), whereas top quintile households have high per capita water consumption (5.9 cubic meters per month) and a small number of family members (2.3). These two trends more or less offset each other leaving household water consumption virtually constant across the income distribution in Uruguay. In addition, due to cramped living conditions, poor households are more likely to share a single connection between several households.

These results indicate that the hypothesized link between income and water consumption does not always hold, and is in general much weaker than is commonly assumed. The implication is that any IBT structure, however well designed, would not be able to redistribute income between rich and poor. Few studies of the distributional performance of IBT structures for water are available for the Latin America region. However, Robles (2002) shows that the IBT structure based on a 15 cubic meter threshold for Paraguay delivers only $20 \%$ of subsidy resources to the poor, but that this percentage would rise to $60 \%$ if the subsistence threshold was reduced to 5 cubic meters. A recent study of IBT structures in South Asia have found that only $20-30 \%$ of subsidies delivered through IBT structures are captured by the poor, and that this share would barely improve even if the design of the IBT structure were to improve, for example by reducing the subsistence threshold (Ragupathi and Foster, 2002). 
In addition, to their reliance on IBT structures, three quarters of utilities in the sample also offer a completely separate social tariff scheme for customers meeting certain poverty criteria, based either on neighborhood or individual characteristics. In most cases, this simply takes the form of a parallel IBT structure offering even more concessional terms and financed internally by each utility through cross-subsidy arrangements. These social tariff schemes offer an average discount of $67 \%$ on what would be paid under the normal residential tariff. In Chile, Colombia, Argentina and Paraguay some more sophisticated social tariff schemes have developed following a range of different practices (Table 10).

Chile introduced a direct subsidy scheme for water in 1990 in order to protect the poorest customers from the impact of the doubling of water tariffs needed to restore financial sustainability to the sector (Gomez-Lobo and Contreras, 2003). The magnitude of the subsidy varies between $15-85 \%$ and is set so as to ensure that households do not have to spend more than $5 \%$ of their income on water. The subsidy is limited to the first 15 cubic meters of monthly water consumption. Eligibility is re-assessed every three years, based on a multi-dimensional poverty indicator that draws upon information collected in a household interview. Administrative costs are shared across a number of social welfare programs that are based on the same poverty indicator. The scheme is funded by the central government and administered by local municipalities, who transfer the subsidy resources directly to the utility contingent on the beneficiaries paying their own share of the bill. The Chilean scheme benefits 600,000 people (or around $20 \%$ of the population) and costs around US\$40 million per year.

Colombia has a unique and long-standing cross-subsidy scheme that applies to all household utility services and presents a number of distinguishing characteristics. It employs a zonal poverty criterion based on a six level social stratification of all neighborhoods throughout the country (World Bank, 2004). Households living in lower strata neighborhoods are eligible for a certain percentage of subsidy, and this is financed by surcharges on the bills of households in higher strata neighborhoods. Both subsidies and surcharges are explicitly identified on consumer bills. The scheme is based on a principle of national income redistribution, so that utilities with surplus surcharge revenues are supposed to transfer them into a fund used to make-up the deficit of other utilities that may have few higher strata households in their customer base. Any overall shortfalls are supposed to be met by fiscal transfers. However, in practice, none of the utilities generate any surplus income, and fiscal transfers made directly to local municipalities are not always used to cover the deficit in the subsidy scheme. The Colombian scheme is estimated to benefit almost 30 million people (or around $90 \%$ of the population). As a result, it is very costly amounting to US\$250 million per year, of which less than US\$100 million is funded via internal surcharges.

A number of Argentine provinces, as well as the metropolitan area, have introduced social tariff schemes for water (Foster, 2004). There are currently some 10 different schemes in operation. While the details differ, most of these schemes select beneficiaries on the basis of multi-dimensional poverty criteria including income, housing characteristics, location and assets. Some schemes are financed through internal cross- 
subsidies (Metropolitan Buenos Aires, Santa Fe, Santiago del Estero), while others depend on fiscal transfers (Chaco, Mendoza, Salta, Tucuman). Notwithstanding the number of schemes, it is estimated that the total number of beneficiaries is less than 100,000 (less than $1 \%$ of the population) and the total cost of these schemes is less than US\$10m.

In Paraguay, eligibility for the social tariff is assessed on the basis of the characteristics of the customer's dwelling (Robles, 2002). In order to be considered eligible for the social tariff scheme households must meet four out of five of the following conditions: earth floors, mud or wood walls, straw or zinc roofs, no more than two rooms, no internal tap and no sewerage. However, the scale of this scheme is very small affecting no more than 5,000 beneficiaries and costing less than US $\$ 0.1 \mathrm{~m}$.

It is interesting to compare the targeting performance of each of these different schemes. Notwithstanding the various selection criteria used, all three schemes present relatively high errors of inclusion, meaning that $30-50 \%$ of subsidy beneficiaries do not fall below the poverty line. As a result, 40-60\% of subsidy resources are captured by the non-poor. At the same time, the Argentine and Chilean schemes with their tightly defined eligibility criteria erroneously exclude $70-80 \%$ of the poor from receiving the subsidy. The Colombian scheme, on the other hand, being virtually universal in reach excludes only $1 \%$ of those living below the poverty line. Finally, the overall distributional incidence of these subsidy schemes is slightly regressive in the Colombian case (given the positive value of the concentration coefficient), but reasonably progressive in the Argentine and Paraguayan schemes. However, it should be noted that the evaluation of these social tariffs is based on simulated rather than observed eligibility and hence is likely to overstate the targeting performance of these schemes.

To put these results in perspective, it is interesting to compare them to those found in other social welfare programs. The Coady statistic takes a value of one for social programs that do no better than to allocate resources randomly across the population, with no particular bias towards rich or poor. Based on a review of 122 targeted welfare programs in 48 countries, Coady and Grosh (2002) find that three quarters of these programs score more than one indicating that resources are concentrated towards low income household. However, the median score was 1.25 indicating that the program allocates $25 \%$ more resources towards poor households than would a random allocation of resources. These authors set a benchmark level of 1.50 for a well functioning targeted welfare program. Thus, the Chilean water subsidy scheme performs better than the typical targeted welfare program and falls just short of the best practice benchmark. However, the Colombian cross-subsidy scheme performs worse than typical welfare programs and is only slightly better than a random allocation of resources, while the Paraguayan scheme comes close to a random allocation of resources. 
Table 10: Comparative overview of water subsidy schemes

\begin{tabular}{|c|c|c|c|c|}
\hline & Argentina & Chile & Colombia & Paraguay \\
\hline $\begin{array}{l}\text { Design } \\
\text { Consumption limit }\end{array}$ & Unmetered & $15 \mathrm{~m}^{3} / \mathrm{m}$ & $20 \mathrm{~m}^{3} / \mathrm{m}$ & $15 \mathrm{~m}^{3} / \mathrm{m}$ \\
\hline Eligibility criteria & $\begin{array}{l}\text { Variable by } \\
\text { Jurisdiction }\end{array}$ & $\begin{array}{l}\text { Household } \\
\text { characteristics }\end{array}$ & $\begin{array}{l}\text { Neighborhood } \\
\text { characteristics }\end{array}$ & $\begin{array}{l}\text { Housing } \\
\text { characteristics }\end{array}$ \\
\hline Discount & $50-70 \%$ & $15-85 \%$ & $30-70 \%$ & $30 \%$ \\
\hline Administration & $\begin{array}{l}\text { Local government } \\
\text { or local utility }\end{array}$ & $\begin{array}{l}\text { Local } \\
\text { government }\end{array}$ & $\begin{array}{l}\text { Local } \\
\text { utility }\end{array}$ & $\begin{array}{l}\text { Local } \\
\text { utility }\end{array}$ \\
\hline $\begin{array}{l}\text { Scale } \\
\text { Total beneficiaries } \\
\text { (as percentage } \\
\text { population) } \\
\text { Total cost } \\
\text { (of which fiscal cost) }\end{array}$ & $\begin{array}{l}0.1 \mathrm{~m} \\
(<1 \%) \\
<\mathrm{US} \$ 10 \mathrm{~m} \\
(<50 \%)\end{array}$ & $\begin{array}{l}0.6 \mathrm{~m} \\
(20 \%) \\
\text { US\$40m } \\
(100 \%)\end{array}$ & $\begin{array}{l}30 \mathrm{~m} \\
(90 \%) \\
\text { US\$250m } \\
(60 \%)\end{array}$ & $\begin{array}{l}5,000 \\
(<0.1 \%) \\
<\mathrm{US} \$ 0.1 \mathrm{~m} \\
(0 \%)\end{array}$ \\
\hline $\begin{array}{l}\text { Performance } \\
\text { Error of inclusion } \\
\text { Error of exclusion } \\
\text { - Connected poor } \\
\text { - All poor } \\
\text { Leakage rate } \\
\text { Coady statistic } \\
\text { Concentration } \\
\text { coefficient }\end{array}$ & $\begin{array}{l}44 \% \\
73 \% \\
76 \%\end{array}$ & $\begin{array}{l}32 \% \\
89 \% \\
96 \% \\
44 \% \\
1.40\end{array}$ & $\begin{array}{l}51 \% \\
1 \% \\
13 \% \\
56 \% \\
1.10 \\
+0.11\end{array}$ & $\begin{array}{l}26 \% \\
82 \% \\
89 \% \\
61 \% \\
0.97 \\
-0.39\end{array}$ \\
\hline
\end{tabular}

Source: Gomez-Lobo and Contreras, 2002; Foster, 2004; World Bank, 2004

\section{Electricity}

The analysis of the electricity sector is based on a detailed review of the tariff structures of some 44 major electric utilities in fourteen countries drawn from around the region (CIER, 2003). Since tariff designs are relatively homogeneous within countries, the discussion will be based on average or modal characteristics at the country level. To complement this general overview, the results of a number of detailed evaluations of existing social tariff schemes are also presented.

In contrast to the water sector, there is a much greater variety of tariff structures in use in the electricity sector (Table 11). Six of the countries surveyed rely primarily on linear tariff schedules for residential customers, while the remaining eight use IBT structures. The three utilities serving Buenos Aires (Argentina) stand out as being the only ones that offer a declining block structure such that the average tariff for residential customers declines as consumption increases. Residential tariff structures are almost always based solely on volumetric considerations, with Chile and Uruguay being the only countries that apply time sensitive and load based charging systems to residential customers.

Nine of the countries in the sample offer parallel social tariff schemes, and the vast majority of these are based on IBT structures, even when the main residential tariff is 
linear (see, for example, Brazil and Colombia). Eligibility for social tariffs is usually confined to households consuming below a certain limit that ranges from 75 kilowatthours per month (Paraguay) to 500 kilowatt-hours per month (Venezuela) and takes an average value of around 200 kilowatt-hours. In a handful of cases additional eligibility criteria are applied based on household characteristics (some Argentine provinces), neighborhood characteristics (Colombia), or whether the family is a beneficiary of other welfare programs (Brazil). The average discount provided to beneficiaries of the social tariff is equivalent to around $40 \%$ on a monthly bill of 100 kilowatt-hours.

\section{Table 11: Overview of tariff structures for residential electricity}

\begin{tabular}{|c|c|c|c|c|c|c|c|}
\hline & \multicolumn{3}{|c|}{ General residential tariffs } & \multicolumn{4}{|l|}{ Social tariffs } \\
\hline & $\begin{array}{l}\text { Volumetric } \\
\text { charge }\end{array}$ & $\begin{array}{l}\text { Time } \\
\text { sensitive }\end{array}$ & $\begin{array}{l}\text { Load } \\
\text { charge }\end{array}$ & $\begin{array}{l}\text { Volumetric } \\
\text { charge }\end{array}$ & $\begin{array}{l}\text { Consumption } \\
\text { limit } \\
(\mathrm{kWh})\end{array}$ & $\begin{array}{l}\text { Other } \\
\text { eligibility } \\
\text { criteria }\end{array}$ & $\begin{array}{l}\text { Discount on } \\
100 \mathrm{kWh} / \mathrm{m} \\
\text { bill }(\%)\end{array}$ \\
\hline Argentina & $\mathrm{DBT} / \mathrm{IBT}$ & & & IBT & $100-200$ & $\checkmark$ & -50 \\
\hline Brazil & Linear & & & IBT & $100-200$ & $\checkmark$ & -50 \\
\hline Chile & Linear & $\checkmark$ & $\checkmark$ & & & & \\
\hline Colombia & Linear & & & IBT & 200 & $\checkmark$ & -50 \\
\hline Ecuador & IBT & & & IBT & 130 & & -16 \\
\hline El Salvador & Linear & & & Linear & 200 & & -3 \\
\hline Honduras & IBT & & & IBT & 500 & & -3 \\
\hline Guatemala & Linear & & & Linear & 300 & & -45 \\
\hline Mexico & IBT & & & & & & \\
\hline Nicaragua & IBT & & & & & & \\
\hline Paraguay & IBT & & & IBT & 75 & & -55 \\
\hline Peru & IBT & & & & & & \\
\hline Uruguay & IBT/Linear & $\checkmark$ & $\checkmark$ & & & & \\
\hline Venezuela & IBT & & & IBT & 200 & & -85 \\
\hline
\end{tabular}

Source: CIER, 2003

It is interesting to examine the design of the IBT tariff structures in more detail, and examine to what extent they repeat some of the design errors that were observed in the IBT structures used in the water sector (Table 12).

First, the size of the subsistence block ranges from 25 to 300 kilowatt-hours per month, with an average value of around 90 kilowatt-hours per month. Based on patterns of appliance ownership and use in Latin America, a subsistence consumption threshold for rural households is generally thought to lie around 40 kilowatt-hours per month (which is sufficient for a few light bulbs and a radio), while the equivalent threshold in urban areas is probably closer to 120 kilowatt-hours (which supports a few light bulbs, a small refrigerator and a modest television). In this sense, the average value of 90 kilowatt-hours per month does not appear unreasonable, although thresholds of 200-300 kilowatt-hours per month as practiced in Colombia and Venezuela are probably excessive.

Second, the gradients of the IBT structures for electricity tend to be steeper for electricity than those observed for water. As a result, in nearly half of the cases considered the average tariff reaches cost recovery levels well within the typical consumption range of a residential household. This can be compared with only $18 \%$ of the cases considered in the water sector. 
Third, both the prevalence and level of fixed charges is much lower in electricity tariff structures than was the case for water. Whereas $94 \%$ of the water utilities surveyed have fixed charges, and $40 \%$ apply minimum consumption thresholds, only $68 \%$ of the electric utilities surveyed have fixed charges, and only $11 \%$ apply minimum consumption thresholds. Moreover, the average value of the fixed charge in the case of electricity is US $\$ 0.66$ per month, compared to US $\$ 2.66$ per month for the water sector. Thus, fixed charges on average represent about $20 \%$ of a typical household electricity bill, versus almost $40 \%$ in the water sector.

Thus, overall, the results suggest that IBT structures for electricity are in general much better designed than is the case for water. Furthermore, the correlation between electricity consumption and household income is somewhat stronger in the case of electricity than was found for the case of water (Figure 12). Thus, households in the top income quintile tend to consume $160 \%$ more electricity than households in the bottom income quintile, compared with $30 \%$ more water, although the variation between the bottom quintile and the middle quintiles is much less pronounced (Figure 13). This suggests that IBT structures in electricity have greater potential to redistribute income than IBT structures in water, to the extent that they are appropriately designed.

Table 12: Overview of IBT structures for residential electricity

\begin{tabular}{|c|c|c|c|c|c|c|c|c|c|c|c|}
\hline & \multicolumn{2}{|c|}{ Fixed charges } & \multicolumn{9}{|c|}{ Block structure } \\
\hline & $\begin{array}{l}\text { Min. } \\
\text { cons. } \\
\mathrm{kWh} / \mathrm{m}\end{array}$ & $\begin{array}{l}\text { Fixed charge } \\
\text { as } \\
100 \mathrm{kWh} \\
\%\end{array}$ & $\begin{array}{l}\text { No. of } \\
\text { blocks } \\
\text { N }\end{array}$ & $\begin{array}{l}\text { Size } 1^{\text {st }} \\
\text { block } \\
\mathrm{kWh} / \mathrm{m}\end{array}$ & $\begin{array}{l}\text { Size } \\
\text { block } \\
\mathrm{kWh} / \mathrm{m}\end{array}$ & $\mathrm{N}^{\text {th }}$ & $\begin{array}{l}\text { Price } \\
\text { block } \\
\text { US\$/kWh }\end{array}$ & $1^{\text {st }}$ & $\begin{array}{l}\begin{array}{l}\text { Price } \\
\text { block }\end{array} \mathrm{N}^{\text {th }} \\
\text { US\$/kWh }\end{array}$ & $\begin{array}{l}\text { Gradient of } \\
\text { block } \\
\text { structure } \\
\text { US\$/kWh }\end{array}$ & $\begin{array}{l}\text { Cost } \\
\text { recovery } \\
\text { threshold } \\
\mathrm{kWh} / \mathrm{m}\end{array}$ \\
\hline Brazil & 0 & 0 & 3 & 30 & 125 & & 0.025 & & 0.070 & 0.0005 & $\propto$ \\
\hline Colombia & 0 & 0 & 2 & 200 & 200 & & 0.046 & & 0.069 & & $\propto$ \\
\hline Ecuador & 0 & 20 & 6 & 50 & 300 & & 0.076 & & 0.112 & 0.0001 & 550 \\
\hline Honduras & 20 & 50 & 3 & 100 & 300 & & 0.047 & & 0.079 & 0.0002 & 1 \\
\hline Mexico & 0 & 18 & 3 & 50 & 100 & & 0.112 & & 0.149 & 0.0007 & 1 \\
\hline Nicaragua & 0 & 0 & 6 & 25 & 1000 & & 0.044 & & 0.257 & 0.0002 & 75 \\
\hline Paraguay & 0 & 0 & 3 & 50 & 150 & & 0.053 & & 0.063 & 0.0001 & $\propto$ \\
\hline Peru & 0 & 6 & 3 & 30 & 100 & & 0.072 & & 0.099 & 0.0004 & 30 \\
\hline Venezuela & 100 & 100 & 3 & 300 & 500 & & 0.057 & & 0.070 & 0.0001 & $\propto$ \\
\hline Average & 13 & 22 & 4 & 93 & 308 & & 0.059 & & 0.108 & 0.0003 & \\
\hline
\end{tabular}

Source: Adapted from Appendix 3 
Figure 12: Average monthly electricity consumption by quintile

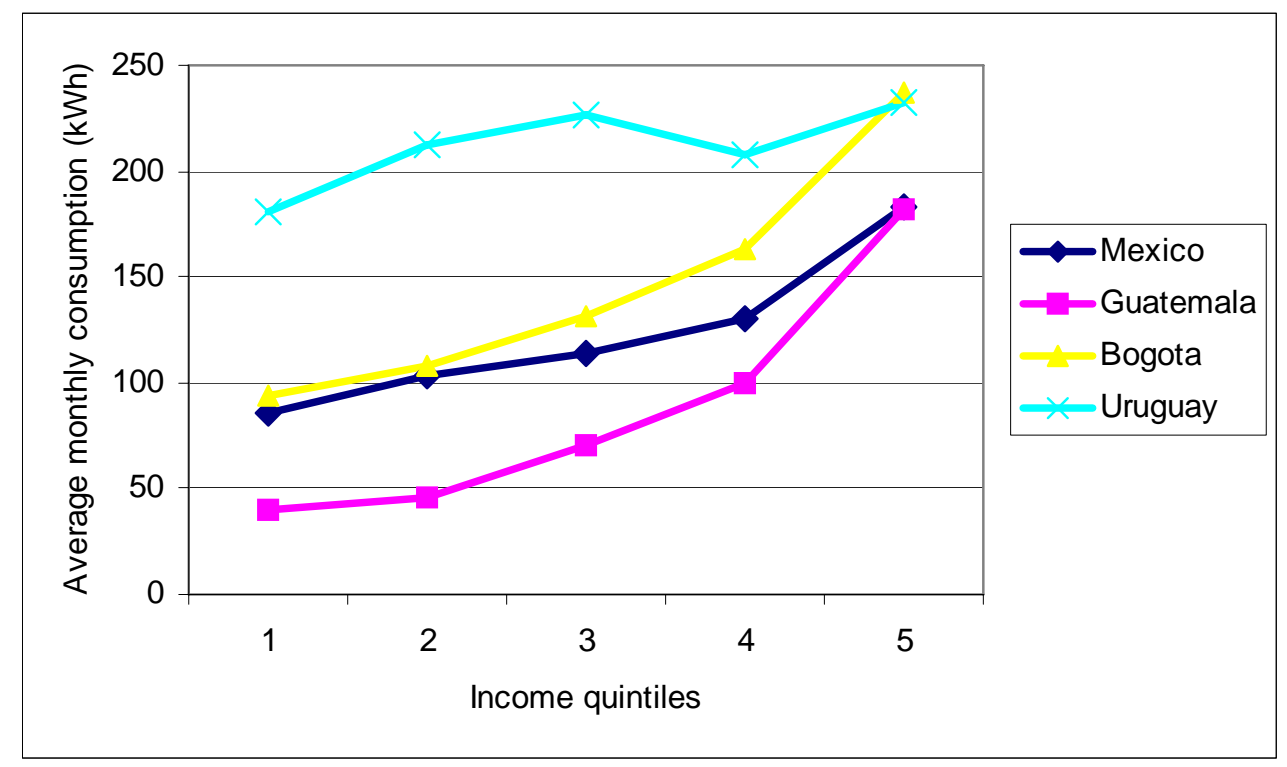

Source: Own elaboration from LSMS household survey data

Figure 13: Index of relative monthly electricity consumption by quintile

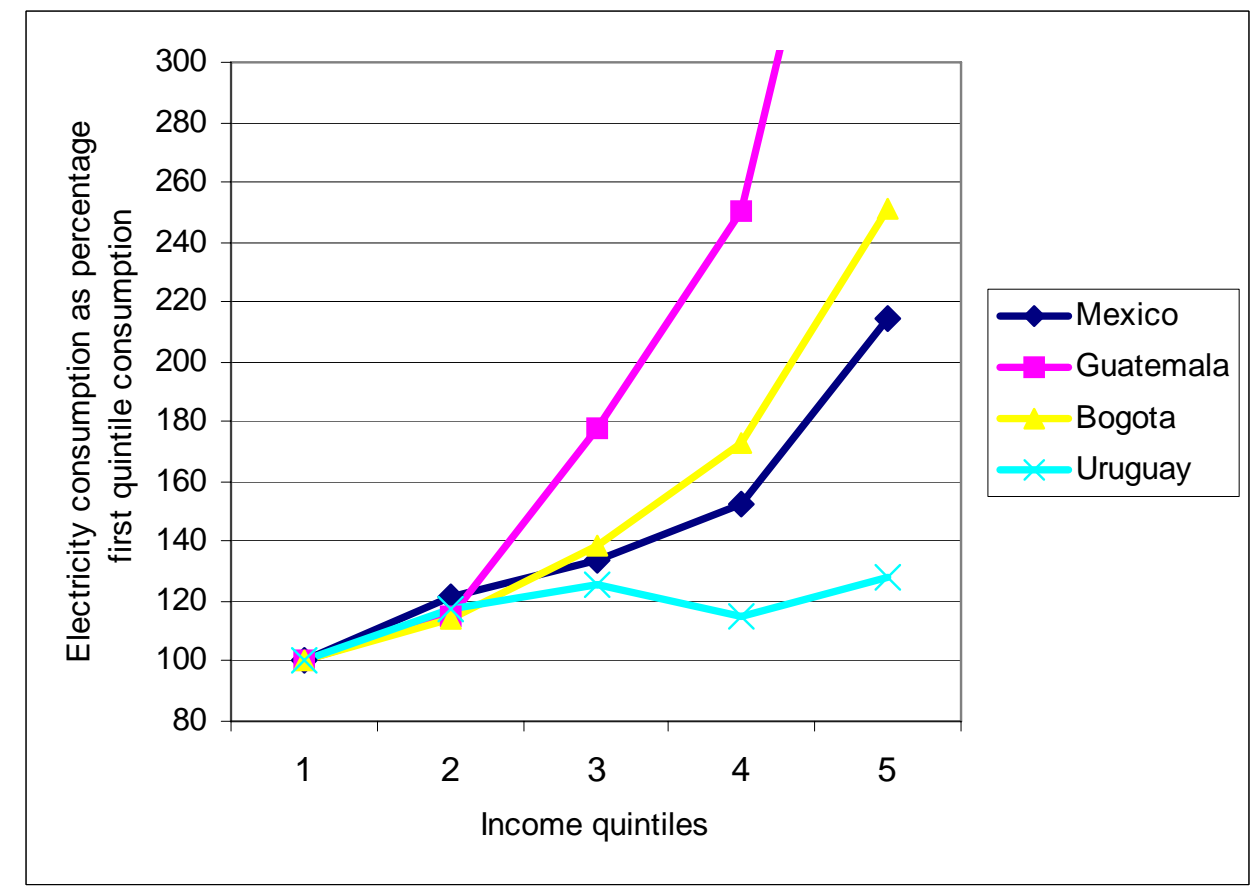

Source: Own elaboration from LSMS household survey data 
Nevertheless, good targeting performance is by no means guaranteed. Table 13 reports performance data on two social tariff schemes in Guatemala and Honduras that use electricity consumption levels as their sole eligibility criterion (Foster and Araujo, 2003; Wodon, Ajwad and Siaens, 2000). However, in both cases the consumption threshold is 300 kilowatt-hours, compared with average household electricity consumption of 102 kilowatt-hours per month in Guatemala and 108 kilowatt-hours per month in Honduras. Thus, $95 \%$ of Guatemalan households and $85 \%$ of Honduran households are eligible for the social tariff, so that $60-65 \%$ of subsidy beneficiaries are not poor, and $80-90 \%$ of subsidy resources are captured by the non-poor. Moreover, only around $50 \%$ of poor households in Guatemala and Honduras have an electricity connection, and consequently $55-60 \%$ of the poor fail to benefit from the social tariff. As a result, both these subsidy schemes are highly regressive and deliver much lower subsidies to the poor than could be achieved via a random allocation of money across the population.

Table 13: Comparative overview of electricity subsidy schemes

\begin{tabular}{|c|c|c|c|c|}
\hline & Argentina & Colombia & Guatemala & Honduras \\
\hline $\begin{array}{l}\text { Design } \\
\text { Consumption limit }\end{array}$ & $100-200 \mathrm{kWh} / \mathrm{m}$ & $200 \mathrm{kWh} / \mathrm{m}$ & $300 \mathrm{kWh} / \mathrm{m}$ & $300 \mathrm{kWh} / \mathrm{m}$ \\
\hline Eligibility criteria & $\begin{array}{l}\text { Variable by } \\
\text { Jurisdiction }\end{array}$ & $\begin{array}{l}\text { Neighborhood } \\
\text { characteristics }\end{array}$ & $\begin{array}{l}\text { Consumption } \\
\text { level }\end{array}$ & $\begin{array}{l}\text { Consumption } \\
\text { level }\end{array}$ \\
\hline Discount & $25-75 \%$ & $10-25 \%$ & $30-50 \%$ & $50 \%$ \\
\hline Administration & $\begin{array}{l}\text { Local government, } \\
\text { and local utility }\end{array}$ & $\begin{array}{l}\text { Local } \\
\text { utility }\end{array}$ & $\begin{array}{l}\text { Local } \\
\text { utility }\end{array}$ & $\begin{array}{l}\text { Central government } \\
\text { and utility }\end{array}$ \\
\hline $\begin{array}{l}\text { Scale } \\
\text { Total beneficiaries } \\
\text { (as percentage } \\
\text { population) } \\
\text { Total cost } \\
\text { (of which fiscal cost) }\end{array}$ & $\begin{array}{l}<0.4 \mathrm{~m} \\
(<1 \%) \\
<\mathrm{US} \$ 20 \mathrm{~m} \\
(0 \%)\end{array}$ & $\begin{array}{l}30 \mathrm{~m} \\
(90 \%) \\
\text { US\$250m } \\
(20 \%)\end{array}$ & $\begin{array}{l}8 \mathrm{~m} \\
(70 \%) \\
\text { US\$50m } \\
(0 \%)\end{array}$ & $\begin{array}{l}\text { US\$17m } \\
(100 \%)\end{array}$ \\
\hline $\begin{array}{l}\text { Performance } \\
\text { Error of inclusion } \\
\text { Error of exclusion } \\
\text { - Connected poor } \\
\text { - All poor } \\
\text { Leakage rate } \\
\text { Coady statistic } \\
\text { Concentration } \\
\text { coefficient }\end{array}$ & $\begin{array}{l}39 \% \\
93 \% \\
94 \% \\
-0.37\end{array}$ & $\begin{array}{l}51 \% \\
2 \% \\
6 \% \\
69 \% \\
1.03 \\
+0.02\end{array}$ & $\begin{array}{l}65 \% \\
0 \% \\
60 \% \\
90 \% \\
0.25 \\
+0.50\end{array}$ & $\begin{array}{l}60 \% \\
9 \% \\
55 \% \\
81 \% \\
0.48\end{array}$ \\
\hline
\end{tabular}

Source: Wodon, Ajwad and Siaens, 2000; Foster and Araujo, 2003; Foster, 2004; World Bank, 2004

It is interesting to compare this performance against two other social tariff schemes that employ additional eligibility criteria, over and above the level of electricity consumption. Two examples are give. The first is the Colombian cross-subsidy scheme, which is based on geographical eligibility, and is virtually identical to the water cross-subsidy scheme already described above. The other is the social tariff scheme practiced in a number of Argentine provinces, based on the socio-economic characteristics of the household, and similar to those already described above for the water sector. Both of these schemes 
appear to perform somewhat better than the consumption based social tariffs in Central America. Both schemes have lower errors of inclusion and a less regressive distributional impact. However, the Argentine provincial social tariff schemes perform significantly better than the Colombian cross-subsidy system, albeit with very high errors of exclusion reflecting their modest scale.

Regarding comparisons with other social programs, the Coady statistic shows that the Colombia, Guatemalan and Honduran schemes all perform well below the median level of 1.25 for targeted welfare programs, and even further below the benchmark level of 1.50 for well-functioning programs. Unfortunately, the Coady statistic for the Argentine scheme could not be computed from the available data.

\section{Conclusions}

During the 1990s, most Latin American countries passed legislation committing themselves to raise water and electricity tariffs towards cost recovery levels. Although nominal water and electricity tariffs increased quite substantially, the combined effects of price inflation and currency depreciation have offset these gains to a considerable degree. Nevertheless, water and electricity tariffs in Latin America remain much closer to cost recovery levels than those found in other developing regions of the world, and are above the average for upper-middle-income countries. However, average residential water tariffs in Latin America at US\$0.41 per cubic meter are still barely 40\% of OECD levels, while average electricity tariffs at US\$0.09 per kilowatt-hour are around $75 \%$ of OECD levels.

Overall, the electricity sector is much closer to cost recovery than the water sector. Thus, while $85 \%$ of countries (and $69 \%$ of low-income countries) achieve some degree of cost recovery for electricity, only $60 \%$ of utilities (and 12\% of low-income utilities) achieve some degree of cost recovery for water. Indeed, even in OECD countries, only around $50 \%$ of water utilities seem to be recovering some degree of capital costs. Moreover, average tariffs for electricity in high-income countries are around twice as high as those in low-income countries, while average tariffs for water in high-income countries are around nine times as high as those in low-income countries.

One of the most commonly cited obstacles to cost recovery tariffs is the problem of affordability of basic utility services by residential households, and low-income families in particular. However, a careful analysis of income distribution in the region suggests that only about $20 \%$ of Latin American households would have to pay more than $5 \%$ of their income for water or electricity services if tariffs were set at cost recovery levels. However, in the region's lower-income countries (Bolivia, Honduras, Nicaragua, and Paraguay), reaching cost recovery tariffs would represent a significant affordability problem for around half of the population. Even in cases where tariffs might have to double to reach cost recovery levels, the overall impact on poverty levels in Latin America would be negligible. 
These results can be compared to those for India and Africa where around $70 \%$ of households could be expected to face difficulties in paying full cost recovery tariffs. In these regions, tariffs would likely have to increase by a factor of ten to reach cost recovery levels, and this could be expected to have a significant impact on poverty. Nevertheless, across all regions, the extent of the affordability problem reduces substantially when incomes are measured in purchasing power parity terms, as may be more appropriate in the case of larger middle-income countries.

Given the relatively small segment of the population that faces genuine affordability problems in Latin America, there appears to be a promising case for using targeted subsidies to reconcile the cost recovery objective with social protection concerns. Social tariff schemes of various kinds are indeed already widespread in Latin America, however they suffer from a number of design flaws. IBT structures are the most prevalent form of social tariffs in the region. These are likely to be more successful in the electricity sector than in the water sector due to the fact that the correlation between consumption and income is much stronger in the case of electricity than water. Moreover, IBT structures in electricity tend to be much better designed than in the case of water, with lower fixed charges, lower subsistence blocks, and steeper gradients. A number of more sophisticated social tariff schemes are also being applied that combine consumption criteria with some form of socio-economic screening. These are generally found to perform better than IBTs, however they also present significant room for improvement. 


\section{Bibliography}

ADB (2004) Water in Asian Cities: Utilities Performance and Civil Society Views, Water for All Series No. 10, Asian Development Bank, Manila

ADERASA, forthcoming Las Tarifas de Agua Potable y Alcantarillado en América Latina, Grupo de Tarifas y Subsidios, Asociación de Entes Reguladores de Agua y Saneamiento de las Américas.

Athukorola, P. and Rajapatirana, S. (2003) 'Capital Inflows and the Real Exchange Rate: A Comparative Study of Asia and Latin America', The World Economy, forthcoming.

CIER (2003) Las Tarifas Eléctricas en los Países de la CIER 2003, Comisión de Integración Energética Regional, Montevideo.

Edwards, S. (1998) Capital Flows, Real Exchange Rates, and Capital Controls: Some Latin American Experiences, Working Paper 6800, National Bureau of Economic Research, Cambridge.

Estache, A. and Gassner, K. (2004) The Electricity Sector of Sub-Saharan Africa: Basic Facts and Emerging Issues, Mimeo, Infrastructure Vice-Presidency, Washington DC

ERRA (2004) Database of Electricity and Natural Gas Prices in Central/Eastern Europe and the Newly Independent States (http://www.erranet.org), Energy Regulators Regional Association, Budapest.

Foster, V. (2004) Towards a Social Policy for Argentina's Infrastructure Sectors: Evaluating the Past and Exploring the Future, Policy Research Working Paper 3422, World Bank, Washington DC.

Foster, V. and Araujo, M.C. (2004) Does Infrastructure Reform Work for the Poor: A Case Study from Guatemala, Policy Research Working Paper No. 3185, World Bank, Washington DC.

Gomez-Lobo, A. and Contreras, D. (2003) 'Water subsidy policies: A comparison of the Chilean and Colombian schemes’ World Bank Economic Review, 17, pp. 391-407

GWI (2004) Tariffs: Half Way There, Global Water Intelligence

EIA (2004) Electricity Tariff Database (http://www.eia.doe.gov/emeu/international/ elecprih.html) Energy Information Administration, Washington DC.

Mejía-Reyes, P., Osborn, D.R. and Sensier, M. (2004) Modelling Real Exchange Rate Effects on Output Performance in Latin America, Discussion Paper No. 035, Centre for Growth \& Business Cycle Research, The University of Manchester, Manchester. 
NIUA (1999), Database of Water Tariffs in Metropolitan Cities of India, National Institute of Urban Affairs, New Delhi

OECD (2004) Electricity Tariffs Database (http://www.oecd.org/statsportal), Organization for Economic Cooperation and Development, Paris.

OLADE (2004) Regional Database of Electricity Tariffs, Quito (www.olade.org)

Kingdom, W., Van Ginneken, M. and Brocklehurst, C. (forthcoming) Full Cost Recovery in the Urban Water Supply Sector: Implications for Affordability and Subsidy Design, Mimeo.

Ragupathi, U. and Foster, V. (2002) 'Can subsidies be better targeted?', Paper 5, Series on Water Tariffs and Subsidies in South Asia, Water and Sanitation Program, New Delhi.

UN-ESCAP (2004) Electricity Tariffs Database (http://www.unescap.org) United Nations Economic and Social Commission for Asia and the Pacific

Wodon, Q., Ajwad, M.I., and Siaens, C. (2000) Targeting Electricity Subsidies: Lifeline or Means-Testing?, Mimeo, World Bank, Washington DC.

World Bank (2004) Colombia REDI: Balancing Social and Productive Needs for Infrastructure, Report No. 30379-CO, World Bank, Washington DC. 


\section{Appendix 1 \\ Implications of Real Exchange Rate Movements}

The real exchange rate aims to measure movements in the relative real purchasing power of two currencies. Thus the real exchange rate $(R)$ is defined as the nominal exchange rate $\left(V_{L} / V_{U S}\right)$, adjusted by the ratio of the foreign price level $\left(P_{U S}\right)$ to the local price level $\left(P_{L}\right)$.

$$
R=\left(\frac{V_{L}}{V_{U S}}\right)\left(\frac{P_{U S}}{P_{L}}\right)
$$

An extensive literature has documented real exchange rate movements in Latin America in recent decades (Edwards, 1998; Athukorala, 2003; Mejía-Reyes et al., 2004). The findings are that in many Latin American countries real exchange rates depreciated substantially following the debt crisis on the early 1980 s, only to experience substantial appreciations up to the currency crises of 1997, and returning to a pattern of depreciation thereafter in a number of countries

Consequently, tariff increases measured in real US dollar terms will tend to be smaller than those measured in local currency terms for countries experiencing real exchange rate depreciation over the relevant period, and conversely for countries experiencing real exchange rate appreciation. In extreme cases, tariff trends in real US dollar terms may even be negative even if the same trends measured in real local currency terms are positive. This would happen for example if there is an increase in relative prices between the respective country and the US that more than offsets the declining value of that country's exchange rate. The opposite situation may also arise.

This phenomenon can be observed in Section 2 of the paper real tariff trends for water and electricity services are analyzed both in local currency and US dollar terms. In some cases (for example Bolivia and Brazil), real water tariffs are reported as rising in real local currency terms but falling in real dollar terms. This is due to real currency depreciations that took place in these countries over the period 1997/03 considered for the water tariff analysis. Similarly, in other cases (for example Paraguay and Uruguay), real electricity tariffs are reported as rising in local currency terms but falling in real dollar terms. Once again, this is due to real currency depreciations that took place in these countries over the period 1990/02 considered for the electricity tariff analysis.

The table below summarizes real exchange rate movements in all of the Latin America countries considered in this paper, over the time periods 1997/03 (used in the water sector analysis) and 1990/02 (used in the electricity sector analysis). 


\begin{tabular}{|l|l|l|l|l|l|l|l|l|}
\hline & \multicolumn{9}{|l|}{ Real Exchange Rate Movement } & \multicolumn{3}{l|}{ S97/03 } & \multicolumn{3}{l|}{ Real Exchange Rate Movement 1990/02 } \\
& 1997 & 2003 & Change & Outcome & 1990 & 2002 & Change & Outcome \\
\hline Argentina & 1.00 & 2.30 & -1.30 & Dep & 0.49 & 1.15 & -0.66 & Dep \\
Bolivia & 5.25 & 6.62 & -1.36 & Dep & 3.17 & 3.82 & -0.65 & Dep \\
Brazil & 1.08 & 2.12 & -1.04 & Dep & 0.00 & 0.02 & -0.02 & Dep \\
Chile & 419.30 & 561.33 & -142.03 & Dep & 304.90 & 346.37 & -41.47 & Dep \\
Colombia & 1140.45 & 1839.77 & -699.32 & Dep & 502.26 & 424.21 & 78.05 & App \\
Costa Rica & 232.60 & 248.03 & -15.43 & Dep & 91.54 & 68.74 & 22.80 & App \\
Dominican R. & 14.27 & 19.62 & -5.35 & Dep & 8.53 & 6.87 & 1.66 & App \\
Ecuador & 1.00 & 1.07 & -0.07 & Dep & 1.00 & 0.71 & 0.29 & App \\
El Salvador & 8.75 & 8.69 & 0.06 & App & 7.59 & 5.33 & 2.26 & App \\
Guatemala & 6.06 & 5.82 & 0.24 & App & 4.49 & 2.96 & 1.53 & App \\
Honduras & 13.00 & 11.21 & 1.79 & App & 4.11 & 3.53 & 0.59 & App \\
Jamaica & 35.40 & 36.59 & -1.18 & Dep & 7.18 & 5.94 & 1.25 & App \\
Mexico & 7.92 & 6.64 & 1.28 & App & 2.81 & 2.06 & 0.75 & App \\
Nicaragua & 9.45 & 6.73 & 2.72 & App & 0.15 & 0.08 & 0.08 & App \\
Panama & 1.00 & 1.02 & -0.02 & Dep & 1.00 & 0.92 & 0.08 & App \\
Paraguay & 2178.00 & 4069.66 & -1891.66 & Dep & 1229.80 & 1806.12 & -576.32 & Dep \\
Peru & 2.66 & 3.21 & -0.55 & Dep & 0.21 & 0.19 & 0.02 & App \\
Uruguay & 9.44 & 17.88 & -8.44 & Dep & 1.17 & 1.31 & -0.14 & Dep \\
Venezuela & 488.63 & 466.85 & 21.79 & App & 46.90 & 35.37 & 11.53 & App \\
United States & 1.00 & 1.00 & 0.00 & App & 1.00 & 1.00 & 0.00 & App \\
\hline
\end{tabular}




\section{Appendix 2 \\ Methodology for Analyzing Household Income Distribution}

Determination of income shares. Data collected from recent household surveys was used to calculate the percentage of total household income (expenditure), that accrues to the urban $\left(S_{U}\right)$ or rural $\left(S_{R}\right)$ sectors of the economy. In addition, the share captured by each percentile $x$ of the urban income (expenditure) distribution is also calculated $\left(S_{x}\right)$

Calculation of standardization of absolute income. In order to have a standardized dollar measure of the income available to each percentile of the income (expenditure) distribution in each country, the national accounts were used to provide a methodologically consistent dollar aggregate. The Gross National Income, GNI, was used to provide the aggregate income, while the Final Consumption Expenditure, FCE, was used to provide the aggregate expenditure. The total dollar income available to each percentile of the urban income distribution is found by applying $S_{U}$ and $S_{x}$ to the GNI (FCE) aggregate. The average dollar income available to each household in each percentile of the urban income distribution $\left(I_{x}\right)$ is then found by dividing this value among the total number of households in each percentile of the urban income distribution $\left(N_{x}\right)$. This value can then be compared against the cost recovery benchmark.

$$
I_{x}=\left[\frac{S_{x} x\left(S_{U} x G N I\right)}{N_{x}}\right]
$$

Current versus international dollars. Two different versions of this exercise are performed. In the first, the Gross National Income (or Final Consumption Expenditure) values are expressed in current US dollars, as is appropriate for analysis of affordability of tradable goods. In the second version, the Gross National Income (or Final Consumption Expenditure) values are expressed in international dollars on a Purchasing Power Parity basis, as is appropriate for analysis of affordability of non-tradable goods. In order to produce the PPP estimates, Gross National Income (or Final Consumption Expenditure) are adjusted by multipliers based on the ratio between Gross Domestic Product in international dollars and Gross Domestic Product in current US dollars.

$$
G N I_{P P P}=G N I_{U S \$} X\left(\frac{G D P_{P P P}}{G D P_{U S \$}}\right)
$$

National versus regional analysis. This whole exercise can be done either at a national level or at an aggregate regional level. In order to produce regional estimates, the percentile shares of all countries in the region are pooled and ordered by income (or expenditure) level. The same statistics are then calculated using population weights to take into account the different sizes of percentiles across countries.

Poverty impact analysis. To calculate the impact of raising utility prices on the incidence of poverty a Laspeyres price index is used to capture the weighted average 
increase in prices, $P$, experienced by each household. The index is weighted based on the initial expenditure shares assigned to utilities, $S_{U}$, versus other goods, $S_{N U}$. Prices of nonutility goods, $\mathrm{NU}$, are assumed to remain constant. The Laspeyres index provides a deflator that is used to scale down the value of household income to reflect its lower purchasing power. Poverty indices are then recalculated based on the deflated vector of incomes, using the original average income of the households in the $40^{\text {th }}$ percentile of the distribution as an ordinal poverty line.

$$
D=\left[S_{U} \times\left(\frac{P_{U 2}}{P_{U 1}}\right)\right]+\left[\left(1-S_{U}\right) \times\left(\frac{P_{N U 2}}{P_{N U 1}}\right)\right]
$$

